University of Louisville

ThinkIR: The University of Louisville's Institutional Repository

Electronic Theses and Dissertations

$12-2006$

\title{
George Morrison, New Albany, and the portrait in 19th century
} America.

Brenna Liane White

University of Louisville

Follow this and additional works at: https://ir.library.louisville.edu/etd

\section{Recommended Citation}

White, Brenna Liane, "George Morrison, New Albany, and the portrait in 19th century America." (2006). Electronic Theses and Dissertations. Paper 1557.

https://doi.org/10.18297/etd/1557

This Master's Thesis is brought to you for free and open access by ThinkIR: The University of Louisville's Institutional Repository. It has been accepted for inclusion in Electronic Theses and Dissertations by an authorized administrator of ThinkIR: The University of Louisville's Institutional Repository. This title appears here courtesy of the author, who has retained all other copyrights. For more information, please contact thinkir@louisville.edu. 
GEORGE MORRISON, NEW ALBANY, AND THE PORTRAIT IN $19^{\text {TH }}$ CENTURY AMERICA

\author{
By \\ Brenna Liane White \\ B.A., Indiana University, 2004

\begin{abstract}
A Thesis
Submitted to the Faculty of the Graduate School of the University of Louisville in Partial Fulfillment of the Requirements for the Degree of
\end{abstract}

Master of Arts

Department of Fine Arts

University of Louisville

Louisville, Kentucky

December 2006 

Copyright 2006 by Brenna L. White

All rights reserved 
GEORGE MORRISON, NEW ALBANY, AND THE PORTRAIT IN $19^{\text {TH }}$ CENTURY AMERICA

By

Brenna Liane White

B.A., Indiana University, 2004

A Thesis Approved on

September 15, 2006

by the following Thesis Committee:

Thesis Director 


\section{ACKNOWLEDGMENTS}

Thank you to my advisor and major professor, John Begley, for helping me understand the museum world and guiding me through the exhibit planning process. I would like to express my appreciation to the other committee members, Dr. Annette Allen and John Whitesell, for their time and observations. Thank you to my parents, Phyllis and William White, who have always been there to help and encourage me no matter what it took. Lastly, I would like to thank my fiancé, Jordan Cundiff, for offering his support and technical expertise throughout the many stages of this project. 


\section{ABSTRACT \\ GEORGE MORRISON, NEW ALBANY, AND THE PORTRAIT IN $19^{\text {TH }}$ CENTURY AMERICA}

Brenna L. White

September 15, 2006

As my curatorial thesis project, I chose to curate an exhibit of George Washington Morrison's paintings. George Morrison was a well-known portrait painter in New Albany, Indiana during his time here from 1840-1893. His paintings are on display in many historic buildings throughout the city and state, including the New Albany Public Library, the Indiana State House in Indianapolis, the Scribner house, and the Culbertson mansion. In addition, Morrison painted prominent members of New Albany society during this period, some of whom are family names still recognized today.

This exhibit, displayed at the Carnegie Center in New Albany, Indiana July 14 - August 26, 2006, will help fulfill their mission of exposing their audience to the history of the city. A presentation of George Morrison's portrait paintings presents the works of an important local artist, addresses the popularity of the portrait-painting genre in America during the $19^{\text {th }}$ century, and brings to light the significant histories of New Albany's citizens that influenced the city we know today. 
TABLE OF CONTENTS

PAGE

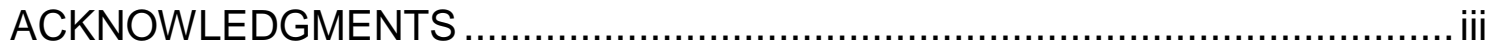

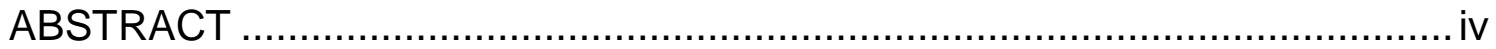

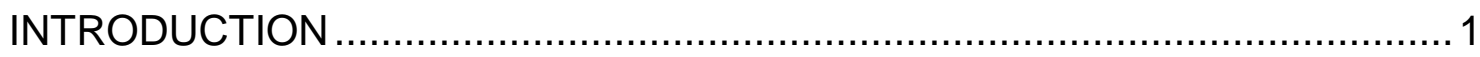

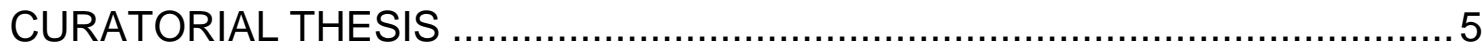

GEORGE MORRISON, NEW ALBANY, AND THE PORTRAIT IN $19^{\text {TH }}$ CENTURY AMERICA ...............................................................

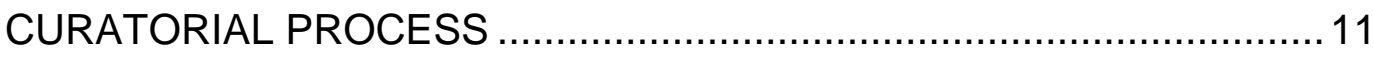

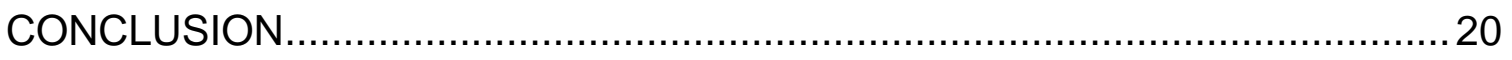

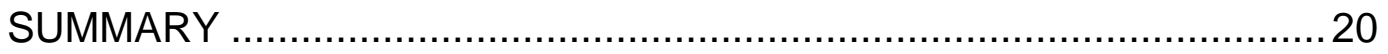

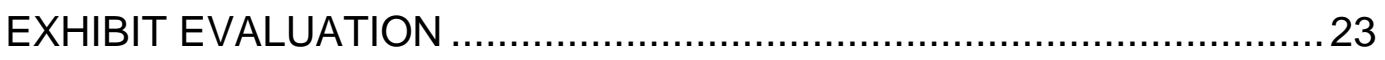

PERSONAL EXPERIENCE …..................................................25

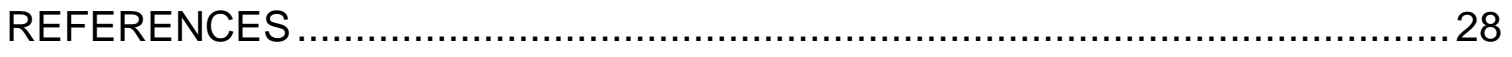

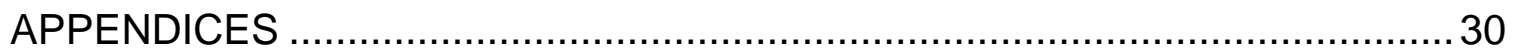

A. THESIS PROJECT PROPOSAL ……...................................... 30

I. LETTER OF PROPOSAL ................................................. 30

II. PROJECT REQUIREMENTS ................................................

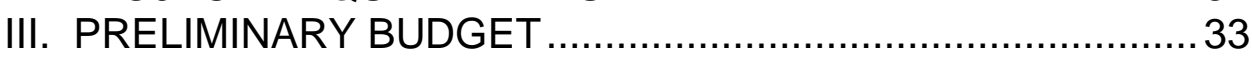

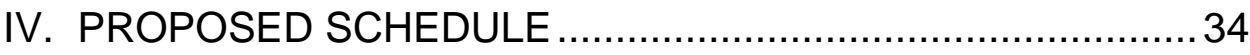

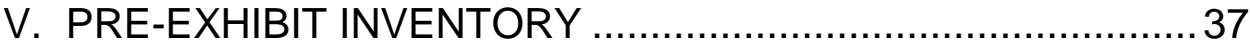

B. EXHIBIT RESEARCH AND LOAN FORMS ….................................40

I. NATIONAL PORTRAIT GALLERY SURVEY FORM ...............40

II. TERMS OF LOAN AGREEMENT ........................................ 43

III. CONDITION REPORT FORM............................................ 44 


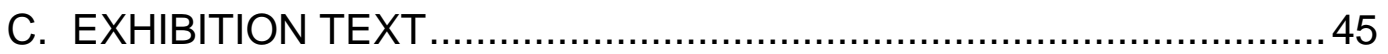

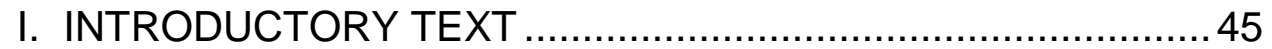

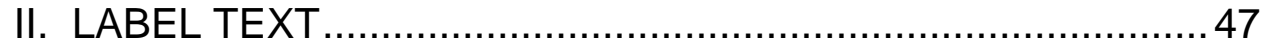

III. GALLERY GUIDE TEXT …......................................... 52

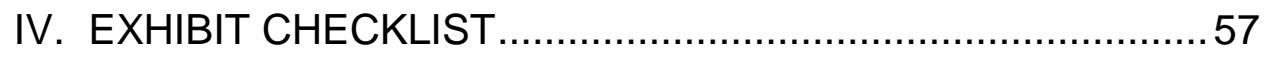

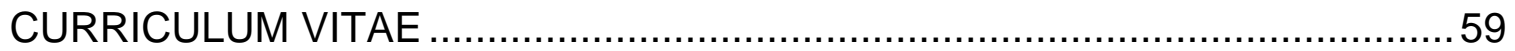

ADDENDUM A -

PROMOTIONAL MATERIALS

I. PRESS RELEASE

II. ANNOUNCEMENT

III. POSTER

IV. GALLERY GUIDE

V. ASHBEL WILLARD PERMISSION LETTER

ADDENDUM B -

EXHIBIT DOCUMENTATION

I. INDIVIDUAL PAINTINGS

II. INSTALLATION 


\section{INTRODUCTION}

An exhibition of George Morrison's paintings was last attempted in 1994 for a single evening event by the Floyd County Historical Society. This exhibit had a very limited audience and the event at the Carnegie Center, which took place from July 14 - August 26, gave many more people the opportunity to view the paintings and promoted a better understanding of New Albany's history.

The exhibit that took place in 1994 was targeted toward a small group of people. Primarily those involved with the Indiana Historical Society were aware of this event, many of whom were already familiar with George Morrison and his subjects. However, the larger event required more interpretive information because it attracted a less informed audience. The Carnegie Center regularly hosts school groups who know little or nothing about George Morrison or the portrait-painting genre. In addition, the Carnegie Center attracts a larger group of people through their advertising campaigns than the Historical Society. Due to the variety of revolving exhibits that the Carnegie Center hosts, their audience and mailing list includes a larger group of people with different interests. Because of the Carnegie Center's larger budget, recognition, and greater advertising experience, this exhibit attracted more publicity than the 1994 exhibit. Not everyone made aware of the exhibit was familiar with New Albany's past and 
the importance of portrait painting in the larger historical context and much more explanation was required.

The audience of the Carnegie Center are members of the Southern Indiana community, primarily Clark and Floyd County, and commonly are between ages 10 and 65 years old. The Carnegie Center audience is predominately female although this exhibit attracted male visitors as well. The historical nature of the exhibit attracted visitors who may not have attended an art exhibit in the past.

This audience required information on George Morrison - who he was, where he came from, what he did, etc. Also, much of the audience was not aware of the importance of portrait painting during this period; It was necessary to explain the business of portrait painting and the status associated with those who could afford to commission such paintings. Lastly, while some visitors may have been familiar with the names of Morrison's subjects, few knew why these people were influential members of society at this time; why were they important?

To address these needs of the audience, I displayed labels for several of the portraits that not only gave the artist and title, but also a brief historical background of the paintings' subject. In addition, I created a brochure that included an essay on portrait painting and George Morrison with select photos of paintings included in the exhibition.

This required a significant amount of research. I consulted the President of the Floyd County Historical society, David Barksdale, who has research the sources used during their 1994 presentation of Morrison's work. Through my 
preliminary research I found a book written by Wilbur D. Peat on the Pioneer Painters of Indiana. This book includes a brief biography of George Morrison, but more importantly, his research and sources were given to the Indiana State Historical Society in Indianapolis. This proved to be a valuable resource. As for information regarding portrait painting as a genre, I consulted art historical resources.

I chose paintings for this exhibit that illustrated George Morrison's association with prominent members of society during the mid 1800s. Many of George Morrison's subjects have been identified although several of those displayed in 1994 by the Historical Society had not been identified at that time. I only included paintings in which the subjects had been determined. I also emphasized George Morrison's importance during this time by exhibiting his painting of Governor Ashbel P. Willard, which is normally on display at the Indiana State House.

I conducted research on the individuals represented in George Morrison's paintings by first speaking with the current owners of the works. Some of the paintings have stayed within the family and they were able to give me some background information. For some I was able to consult the paintings' provenance, which helped in explaining the paintings history and subject, such as determining whether the painting was done posthumously, another aspect of portrait painting that will need to be addressed in text labels or in the gallery guide. Other paintings, such as that of Dr. William Scribner, are on display at 
historic sites that have information regarding the subjects. The historical societies in the area served as an important resource as well. 


\section{GEORGE MORRISON, NEW ALBANY, AND THE PORTRAIT IN $19^{\text {TH }}$ CENTURY AMERICA}

Portraiture has served a documentary purpose throughout history. Popularized in ancient times, a portrait serves as a representation of wealth and power. The earliest forms of portraiture were pre-historic funerary paintings of the dead. Later, the Egyptians believed that a portrait helped ensure immortality for the deceased. During the $16^{\text {th }}$ century kings and queens requested paintings of themselves. These royal portraits served as political propaganda, promoting the individual's political persona and presenting a personified image of the nation. ${ }^{i}$

Members of the upper classes commissioned portrait paintings to serve as status symbols. Impressively portraying the subject is the primary purpose of the portrait. British patrons continued the tradition of respect for the dead and personal promotion by including the portrait in a form of ancestor worship. Elite British families commonly displayed numerous paintings of ancestors throughout their homes, advertising their impressive genealogy." The interest in portrait painting came to America with the early settlers and continued to develop with later generations. 
During the $19^{\text {th }}$ century, portrait painting became an especially prosperous business. Americans experienced increasing economic success and the benefits of urban growth. Nearly every community could support at least one portrait painter. ${ }^{\text {iii }}$ Wealthy Americans sought to associate themselves with the established wealth of the British elite by continuing the tradition of portraiture. Americans commissioned portraits of themselves and their families, carrying on the British custom of aggrandizement.

George Morrison began working as a portrait painter during this period, coming to New Albany in 1840. Born in Baltimore, Maryland, George Morrison moved to New Albany at the age of 20. In 1841, Morrison opened a one-room art gallery on High Street, now known as Main Street, where he displayed and sold his paintings, establishing his business as a portrait artist. Morrison later purchased a 25-acre site in Silver Hills where he lived with his wife Lydia Maynard, a native of New Albany, and their children.

During his time in Indiana, Morrison painted portraits and landscapes throughout the southern region of the state, including the cities of New Albany, Evansville, Terre Haute, Bedford, Bloomington, as well as Indianapolis. Morrison exhibited at the second State Fair in 1853 and won the first place award of $\$ 15.00$, the equivalent of $\$ 350.00$ today. George Morrison lived and worked in New Albany until his death in 1893 . His success as an artist in the portraitpainting genre suggests that Morrison was both talented and able to produce work that followed the accepted style of the day. George Morrison's paintings 
help us understand characteristics of the popular portrait painting genre in mid $19^{\text {th }}$ century America.

Although other artists traveled through the area, George Morrison worked as New Albany's principal portrait painter, establishing himself as the city's preferred artist. Many of New Albany's leading citizens commissioned his paintings, including the Scribner, Meekin, Kraft and Shrader families, in addition to political figures such as Indiana Governor Ashbel Willard. Each of these families and individuals experienced economic success and chose to express this by having their portraits painted by Morrison. The portraits painted for these affluent individuals conveyed an image of wealth and prosperity.

This image of success was communicated through the appearance of the individual. While the face is the most significant part of a portrait, clothing and hair occupy much more of the painting. The individual's clothing reflects the social and economic aspirations as well as cultural values of the person, creating a visual biography of the subject. ${ }^{\text {iv }}$

Although individuals wanted themselves depicted as "well-to-do," it was also important to be seen as respectable "god-fearing" members of society. The portrait of Dora Meekin Boardman reflects this desired image of a wealthy yet respectable woman. Mrs. Boardman wears a decorative lace collar and brooch with a traditional black dress. Decorative accessories, such as jewelry and lace, were acceptable but kept to a minimum.

A child was not expected to dress as conservatively as an adult and commonly reflected the affluence of the parents. Morrison's painting of Cleon 
Meekin depicts the young girl with curls in her hair wearing a formal white dress and gold locket. These decorative details are symbols of the prosperity and social standing of the Meekin family. The clothing worn by these individuals conforms to the propagandistic tradition of the portrait.

In addition to representing the family's success, portraits of children occupied a special place in the hearts and homes of their parents and relatives. The childhood mortality rate remained high during the $19^{\text {th }}$ century prompting parents to commission paintings of their children at a young age or "mourning pictures," portraits painted after a child's death. These portraits served as mementos for the parents after a child had reached adulthood or passed away.

Portraits of children were often painted full-length and in a natural setting. Artists frequently depicted children playfully, with a small pet as a symbol of youth and innocence, adding to the sentimental nature of these paintings. ${ }^{v}$ These aspects of childhood portraiture reflect the Romantic ideals of nostalgia and sentimentality popularized in the Victorian era. Those who could afford portrait paintings could afford to appreciate their children as more than another member of the family work force. George Morrison's portraits of children convey society's emerging interest in childhood as a distinct and precious stage of life.

Each of George Morrison's portraits reflects his unique style and interpretation of his subjects. Despite his detail-oriented technique, Morrison gives individuals a mild, genial appearance. One of his most significant and valued paintings is a portrait of Governor Ashbel Willard painted in 1857 and normally displayed at the Indiana Statehouse in a collection of Governors' 
paintings. Morrison depicts Willard standing in a firm pose, addressing the viewer, with a calm and warm expression. ${ }^{\text {vi }}$ Although many of his subjects appear to confront the viewer, Morrison instills individuals with a tranquil appearance, making his portraits appear less intimidating and more inviting.

Although Morrison specialized in portraiture, he created a number of acclaimed landscape paintings. These views of New Albany and the surrounding Ohio Valley region reveal society's ambivalent feelings of optimism and yet apprehension for the future. Morrison demonstrates society's optimism through the pristine images of steamboats and far-off views of the city. George Morrison's use of distance in his landscapes offers a reflective image rather than involving the viewer in the hustle and bustle of everyday life. The use of "soft light" expresses the artist's idealized view of a world quickly fading away. vii

George Morrison's Landscapes are not unique in that they draw on the example of other artists during the mid to late $19^{\text {th }}$ century, reflecting society's overall view of the utopian world of the past and ambivalence toward the future. These nostalgic images are appropriate and predictable during a period of rapid change when Americans were inspired by the potential of emerging scientific discoveries and coming age of industrialization but fearful that this change would result in the loss of traditional ways of living. ${ }^{\text {viii }}$ George Morrison's paintings clearly conveyed this optimism while also expressing nostalgia for a world that was rapidly changing.

The work of George Morrison helps us understand the political and social values held in $19^{\text {th }}$ century New Albany. From conveying success and identity 
through adult portraiture giving the viewer a sense of who this person was to expressing feelings of nostalgia with landscapes and portraits of children, these paintings are best understood as reflections of life in America during the mid1800s. Although portraiture has evolved with the widespread use of the camera and changing artistic movements, portraits remain a popular form of art and a means to present a desired image to the world. Morrison's paintings reveal the continuing adaptation of the portrait-painting genre to satisfy the needs of its subjects and their society in addition to demonstrating the political and technical skills of an accomplished local artist.

\footnotetext{
' Malcolm Warner, Portrait Painting, 5-9.

ii Robin Simon, The Portrait in Britain and America, 9.

iii William H. Gerdts, "Natural Aristocrats in a Democracy: 1810-1870," 27.

iv Wayne Craven, Colonial American Portraiture, 29.

$\checkmark$ "Seen But Not Heard: Images of Children from the Collection of the Boston Athenæum."

${ }^{v i}$ Wilbur D. Peat, Portraits and Painters of the Governors of Indiana 1800-1978, 36.

vii Elizabeth Bryant, "Landscapes in America 1850: Dreaming of Paradise," 1-5

viii Elizabeth Bryant, "Landscapes in America 1850: Dreaming of Paradise," 1-5.
} 


\section{CURATORIAL PROCESS}

Once the Director of the Carnegie Center, Sally Newkirk and my advisor, John Begley, approved the George Morrison exhibit, I began preliminary research on the artist and current ownership of his paintings. David Barksdale, President of the Indiana Historical Society, had assembled a display of 34 George Morrison's paintings for an evening reception at the New Albany - Floyd County Public Library in 1994. I began my research by meeting with Mr. Barksdale who was able to provide me with the 1994 locations for many of the paintings, photos of the paintings at that time, and some basic biographical information on the artist.

My first priority when planning this exhibition was locating the paintings. Although the New Albany-Floyd County Library had a large collection of Morrison paintings, these would not be enough to fill the Carnegie Center's gallery space. In addition, the library displayed many of their George Morrison paintings in a permanent exhibit on the lower level of the library; the public could view these anytime. I wanted to expose my audience to portraits that are not available to view on a regular basis, those from private collections. Locating these portraits would prove to be difficult at times but ultimately rewarding. David and Sally were very helpful during this planning stage. Each of them are not only involved in historical and cultural organizations but they are also long-time residents of 
New Albany; they were able to provide basic history of the city and guide me towards those they personally knew owned paintings.

As I stated in my proposal, I was specifically interested in including paintings that had been identified and would thus demonstrate Morrison's popularity among New Albany's elite citizens of the time. I began contacting individuals from David Barksdale's list who owned paintings that fit my criteria. David's list included addresses so my first step was to send out letters explaining the Carnegie Center, the Morrison exhibit, its purpose, and the dates it would be on display. Only two of my letters were returned. A couple of weeks later, I began calling the individuals to confirm that they had received my letter, whether they still owned the painting, whether or not they were interested in loaning the painting for the exhibit, and the physical condition of their painting.

Several of the paintings were owned by organizations. The Kraft and Shrader families have operated funeral homes since George Morrison's lifetime and are very recognizable names in the local community, making these paintings appropriate for the exhibit. The Kraft family own three paintings: George Kraft, John Briggs, and Mary Briggs. The Shrader family owns paintings of John and Margaret Shrader. These family names would be recognized by many New Albany residents, reinforcing Morrison's connection to the city's history and his association with the elite businessmen of the day.

Both the Kraft and Shrader funeral homes were happy to loan their paintings, with a few minor concessions; the Shrader funeral home required that we pick up and deliver their paintings. The Kraft funeral home was reluctant at 
first, due to a previous experience with the Carnegie Center but agreed to the loan after talking with Sally Newkirk. However, the Kraft family emphasized they would require exact documentation of the loan terms and dates the items would be in the Carnegie Center's possession. In addition, the Krafts required a framed poster to put up in their Funeral Home to fill the prominent space the painting of George Kraft normally occupied.

I then contacted the Scribner House, which is managed by the Daughters of the American Revolution. Their regent Nona Bell informed me that the proposal would need to be voted on at their meeting in February, although she did not anticipate a problem. The loan was approved with the provision that we would be responsible for picking up and returning the pieces. The Scribner family founded New Albany and their home, the city's first frame house, is located on Main Street. Grade school students visit the Scribner House annually. The paintings of Dr. William Scribner, Charles "Little Eddie" Scribner, and Harriet Hale Scribner would be important to the exhibit due to their recognition. In addition, Dr. William Scribner's portrait had been restored within the past 10 years and the other two remained in excellent condition and therefore would be a centerpiece of the exhibit.

Another centerpiece of the exhibit was Governor Ashbel Parsons Willard. George Morrison's portrait of Willard is part of the Indiana State House's collection of Governors' portraits. I contacted Indiana Senator Connie Sipes through e-mail about loaning this painting. Senator Sipes promptly put me in touch with Pam Bennett, curator of the Indiana Historical Bureau who is in charge 
of the Governors' paintings. Ms. Bennett agreed to the loan with the condition that we would be responsible for transportation. Governor Willard's portrait has not been displayed in New Albany since Morrison painted the portrait in 1857. This painting illustrates George Morrison's status as a respected artist, considered worthy of painting such an important political figure as Ashbel Willard. The portrait of Governor Willard is also noted in Wilbur D. Peat's Pioneer Painters of Indiana as Morrison's most important work.

Another individual that I chose to include in the exhibit was Anna Humphries Weir, owned by David and Barbara Cannon. The Cannon's portrait was in good condition and the Cannon's were more than happy to be included.

Sally Newkirk owned a Morrison portrait of "Mrs. Michael C. Kerr." Michael C. Kerr was a very prominent citizen in New Albany, practicing law and later becoming a member of the State house of representatives. However, the subject of this painting was his wife and I was not willing to simply label her as "Mrs. Michael C. Kerr." I looked up information on Michael C. Kerr but his wife's name was not mentioned. However, after making a few phone calls to the researchers at the Indiana room of the New Albany-Floyd County Public Library, her name was discovered to be Mary H. Coover. Because Michael C. Kerr was more recognizable, his home is marked with a historical marker in downtown New Albany, I decided to label her as Mary Kerr with Mrs. Michael Kerr in parentheses. Again, this portrait demonstrated the recognition Morrison received as a portrait painter by being asked to paint a prominent political figure's wife. 
Phyllis and Sonny Thomas of Madison Indiana were the final people from David Barksdale's 1994 list of Morrison paintings and locations that I was able to contact. Phyllis and Sonny own a portrait of Emma Dora Townsend, a young girl who died shortly after the painting had been completed. I was interested in this painting to be included in a section on children's portraiture. I was aware of paintings of children at the library and interested in the less formal but more elaborate composition of children's portraiture. Phyllis was more than happy to loan the painting although Sonny, a State Farm insurance agent, was hesitant for insurance reasons. Sonny was particularly interested in having the painting appraised. Sally and I put them in contact with several antique appraisers but made it clear that the Carnegie Center would be unable to pay for any appraisal they decided to have done. In the end, Phyllis and Sonny Thomas decided to loan their painting of Emma Dora Townsend to the exhibit.

One of the antique dealers Sally contacted in regards to having the Emma Dora Townsend portrait appraised was interested in loaning their own painting to the exhibit. Rod Lich and Susan Parrett own a portrait of an unidentified child that is signed and dated in addition to a steamboat landscape on wood panel that they believe to be a Morrison. Although I decided not to include the steamboat painting, I did include the child's portrait. I had avoided including portraits of unidentified people in the exhibit; however, it did not seem as important for a child's portrait. This painting would fit well in the section of the exhibit on children's portraiture where the subject was not as important as the concept behind the paintings. 
In addition to the loaned paintings described above, the New Albany-Floyd County Public Library has 11 Morrison paintings in their collection. The Carnegie Center is part of the Public Library and we had no problem loaning the paintings we needed for the exhibit. Several of the Library's paintings are regularly on display in the downstairs area next to the Indiana room. The Indiana room is located down the hall from the children's area, which has resulted in scratches across the bottoms of many of the paintings. The paintings that have been slightly damaged are stored in the Indiana room's storage area.

Four of the paintings I wanted to include from the Library's collection had been in storage due to these minor scratches. George Morrison's self-portrait, Lydia Maynard Morrison (George Morrison's wife), John Owen Greene, and the landscape View from Spickert Knob had all been taken off display. The Carnegie Center's exhibit would give the public another opportunity to view these paintings and possibly create a more urgent interest in restoring them. Other paintings included from the Library's collection were Mary Morrison (George Morrison's daughter), another Self-portrait, and a landscape View of New Albany. The library had several other notable Morrison paintings; however, these were not included in the exhibit because we ran short on space and these were already on permanent display at the Library.

Once I had secured these paintings, I began to look into contacting individuals whose letters had been returned. I had originally sent a letter to Jean Hansen who owned paintings of the Meekin family. I later found out that Jean had passed away and began making phone calls to those who knew the Hansen 
family; however, no one seemed to know much about who took the paintings except that she had a son and daughter in St. Louis. Sally Newkirk found a letter a couple of weeks later from Merrell Hansen. Merrell lived in St. Louis and left her number in case the Carnegie Center ever wanted to have an exhibit on the Meekin family. The Meekins were another prominent and successful family during the mid 1850s, involved in the shipping industry. The portraits of Martin Meekin, Cleon Meekin, and Dora Meekin Boardman were included in the 1994 exhibit and I had photographs of them that David Barksdale provided. I not only wanted these paintings due to the recognition of the Meekin name but also because this was a complete family and the little girl's portrait was especially compelling. In addition, the paintings stood out because of their oval frames. We contacted Merrell Hansen and she even volunteered to drive the paintings down from St. Louis for the exhibit.

I continued by contacting institutions in the New Albany and Louisville area, including Historic Homes and museums, attempting to locate other Morrison paintings. I only found one institution that owned any George Morrison paintings, the Filson Historical Society. Jim Holmberg was willing to loan a portrait of Philip Lightfoot Lee, a member of the Kentucky State Legislature and Captain of the State Guard during the Civil War, and a small landscape "Steamboat and Barge at Sunset," which had recently been restored. These paintings demonstrated George Morrison's varied subjects and importance as a portrait painter outside of New Albany. 


\section{Arrangement}

After I had located and determined the paintings to be included in the exhibit, I began considering how I would like to arrange the paintings. I had located several families' portraits, including the Briggs, Scribners, Meekins, and Shraders. These were all very influential and recognizable names in New Albany. I wanted to keep these paintings together in the right gallery. Along with the paintings of Morrison and his family, these would serve as the introduction to George Morrison and his reputation among the elite.

I had also arranged to loan several portraits of individuals who were either important political figures, such as Governor Ashbel Willard, or simply showcased Morrison's variety, such as Anna Humphries Weir. These paintings would need to stay together as well. The paintings of the children, John Owen Green, Emma Dora Townsend, and the Unidentified child would be appropriate for the section I had planned to discuss aspects of children's portraiture. Finally, the landscapes of New Albany and the surrounding area would be the concluding section, which would exhibit Morrison's varied interests and talents as well as play on the exhibits title “George Morrison (1820-1893): New Albany's Portrait Painter."

I spent quite a bit of time collecting the measurements for the paintings and arranging them on the Carnegie Center's wall in the very basic Microsoft $(\subset$ program Paint. Figuring out how to keep all of the family's together without crowding the gallery was difficult and eventually required that I take out paintings from the library that had originally been included. In the end, I believe that 
planning how I wanted the gallery organized early made things much easier once it was time to set up. 


\section{SUMMARY}

The "George W. Morrison (1820-1893): New Albany's Portrait Painter" has reignited interest in George Morrison and his paintings. By exposing the works of this significant local artist to the community, people are again talking about Morrison and his family and a renewed interest has been taken in preserving his paintings. In addition, other Morrison paintings are being discovered and documented. This exhibition has sparked much community discussion.

Since the opening of the Morrison show, many individuals have surfaced who have their own Morrison stories. One visitor who used to work at the library in the Indiana room asked the question, 'Where are George Morrison Jr.'s paintings?" In my research I had found reference to a son and a daughter, Frank and Mary Morrison; however, George Morrison apparently had a second son, George W. Morrison Jr. who disappeared not long after his father's death, according to a newspaper article the visitor provided. The article also specifies that George Morrison Jr. was a portrait and landscape artist as well. This may explain why several of the paintings at the library that appear much less refined are signed and credited to George Morrison. 
Because of these questions, the Carnegie Center asked Estill Curtis Pennington, a fine art consultant, to give a gallery talk on Aug. 19th and possibly identify paintings that may not be George Morrison Sr.'s work. Pennington provided insight into the antebellum period that influenced the portraits as well as Morrison's own background. He even suggested that Morrison had probably worked as a sign painter or draftsman due to the linear composition of the portraits. Although he did not not offer any conclusion, Pennington was fairly certain that the majority of the paintings in the gallery were done by George Morrison Sr.

The display of these paintings and recent acquisition of Morrison's rosewood piano by the Floyd County Historical society has helped renew interest in the artist and his paintings. The New Albany - Floyd County Free Public Library keeps many of these paintings in storage due to preservation issues and minor damage from being displayed in the past. By displaying these paintings and demonstrating the community's interest, it is likely that their conservation and repair will become a greater priority. Rod Lich and Susan Parrett have expressed interest in helping preserve the landscape View of Spickert Knob, and I am hopeful that others will contribute to the conservation of paintings as well.

A benefit of this exhibit is the documentation of Morrison and his paintings. The information I have compiled on Morrison and the current locations of his paintings will be given to the Carnegie Center for Art and History and the Floyd County Historical Society. In addition, I have contacted the National Portrait Gallery and arranged to send photos and documentation on the paintings I have 
included in this exhibit as well as others that have been discovered as a result of the exhibit. 


\section{EXHIBIT EVALUATION}

The Carnegie Center monitors their attendance with sign-in sheets. I created a sign-in sheet specifically for this exhibition that tracked the visitors by name, age, and hometown. I also asked the visitors if they found the George Morrison exhibition entertaining and informative, in addition to whether or not they would be interested in attending other historical exhibits in the future. I also asked how they heard about the George Morrison exhibit. I specifically wanted to know how effective the poster advertising had been.

After reviewing the exhibit sign-in sheet, it appears that approximately 250 people saw the exhibit over the six-week period from July 14 - August 26. This number includes the 63 who attended opening night and the 35 who attended Estill Pennington's talk on August 19th. Although not everyone gave their age, about $36 \%$ of those who attended were 61 and over and $31 \%$ were between 46 60 , the remaining $33 \%$ were between 18 and 45 . This corresponds with the Carnegie Center's average attendance age.

Those who completed the sign-in sheet were impressed with the exhibit and interested in attending other historical exhibits in the future. They did not offer many suggestions or further comments.

The majority of those who attended the George Morrison exhibit were already on the Carnegie Center's mailing list and heard about it through the 
announcement cards. A few specified that they had seen the Courier-Journal article printed the week before the opening but most others heard about the exhibit through word-of-mouth. No one specifically noted that they had seen the posters that I placed in coffee shops, libraries, and schools; therefore, I do not believe they were a very effective method of advertising. However, this may just mean that those who did notice the posters and attended the show had heard of the exhibit through other advertising outlets as well. 


\section{PERSONAL EXPERIENCE}

I believe that the exhibit was successful in meeting the goals I expressed in my proposal. Although I had planned each step, I was not able to anticipate everything that would be necessary for the show to come together. As discussed in the Curatorial process section, some donors had certain needs that had to be accommodated before they would agree to loan their paintings. The experience of planning this type of exhibit, involving valuable artwork from private collections, helped me understand the many compromises that must be worked out before an exhibit can take shape. Locating the artwork, planning the delivery, and addressing insurance concerns occupied much more of my planning time than I had anticipated.

With this in mind, I would have liked more time to plan the exhibit. I began working on the exhibit in December 2005, giving me a little over seven months to complete the project. However, I soon realized that not many people were interested in discussing plans for a George Morrison exhibit during the month of December and early January. Once I was able to get letters out to prospective lenders, it took another month or so to get in touch with them to discuss the details. The process of locating the pieces and getting in touch with the owners took about four months of my time. Although I had been researching 
George Morrison and the portrait-painting genre during this time as well, most of my time was occupied with locating the artwork.

Once I had the paintings secured, I had to begin working on the poster and announcement design. This process also took quite a while. My fiancé, Jordan Cundiff, was familiar with photo shop and helped design the image that would be used for both the poster and the announcement card. I knew what I wanted the image to look like and chose to use a self-portrait from a painting Morrison had done of himself painting a landscape. This painting was in storage at the library and it was difficult to get a decent photograph; however, once I had the photo, Jordan was able to manipulate the image so that it would be appropriate for my design.

I also did not have the time to see many of the pieces included in the show until they were picked up or delivered. I had asked each donor if their painting was in good condition and had photos of most paintings from the 1994 exhibit; however, some of the paintings were not in the condition I expected when they arrived. For example, the portrait of Margaret Shrader had to be taken out of the show because the Carnegie Center's lights amplified the poor condition of the painting. I should have made viewing the paintings in person a greater priority.

The final issue I experienced is also related to a lack of time. I had originally planned to do more research on the subjects of each painting. I am glad that I chose not to print text panels on each individual as I originally intended because it would have been an overwhelming amount of text. However, I would 
like to have had more knowledge of the individual's portrayed in the exhibit to share with curious visitors. 


\section{REFERENCES}

Bryant, Elizabeth. "Landscapes in America 1850: Dreaming of Paradise." http://www.tfaoi.com/aa/5aa/5aa177a.htm.

Craven, Wayne. Colonial American Portraiture, Cambridge: Cambridge University Press, 1986.

Gerdts, William H. "Natural Aristocrats in a Democracy: 1810-1870." Quick 27-60. http://www.tfaoi.com/aa/5aa/5aa178.htm.

Johns, Barbara. "Landscapes in America 1850-1890."

Peat, Wilbur D. Pioneer Painters of Indiana, Indianapolis: Art Association of Indianapolis, Indiana, 1954.

Peat, Wilbur D. Portraits and Painters of the Governors of Indiana 18001978, Indianapolis: Indiana Historical Society, 1978.

Quick, Michael, ed. American Portraiture in the Grand Manner: 17201920, Los Angeles: Los Angeles County Museum of Art, 1981. 
Quick, Michael. "Princely Images in the Wilderness: 1720-1755." Quick 10-20.

"Seen But Not Heard: Images of Children from the Collection of the Boston Athenaeum." http://www.tfaoi.com/aa/5aa/5aa283.htm.

Simon, Robin. The Portrait in Britain and America, Boston: G.K. Hall and Co., 1987.

Warner, Malcolm. Portrait Painting, Oxford: Phaidon Press Limited, 1979. 


\section{APPENDIX A \\ THESIS PROJECT PROPOSAL}

\section{Letter of proposal}

March 10, 2006

Mr. Begley,

I am interested in hosting a show titled George Morrison (1820-1893): New Albany's Portrait Painter. This exhibit will take place during the month of July 2006, during which time the Floyd County Historical Society will be receiving a piano formerly owned by the portrait painter.

George Morrison was New Albany's primary portrait painter from 1840 until his death in 1893. He painted many of New Albany's prominent citizens during this time, including Dr. William Scribner and Governor Ashbel P. Willard. I would like to focus not only on the work of George Morrison but also on the history he presents through his subjects and the social implications of the portrait-painting genre. This exhibit is highly appropriate to the Carnegie Center's mission of promoting "...the history and heritage of Floyd County."

The following proposal includes a summary of the project: issues this exhibit will address, background on the subject, and the approach I plan to take. I have also included the requirements of the project, and a basic timetable.

Thank you for your time and consideration,

Brenna White 


\section{Project requirements}

The primary requirement for this project will be time. I have information on the locations of the artwork from the Historical Society's presentation in 1994; however, contacting these owners, locating pieces that have changed hands, and possibly finding other paintings will take a considerable amount of time. Once I have located the artwork to be included in the exhibition, shipping costs may be an issue, although I expect that most paintings will be dropped off and picked up by the owners. All paintings will require condition reports and temporary custody paperwork.

Conducting the research required to present the subject will require time and some travel. The Indiana Historical Society is located in Indianapolis and has a collection of information on George Morrison and portrait painters of this period. I will need to meet with owners of these paintings and conduct research on the subjects at historical sites and institutions throughout Louisville and Southern Indiana.

The installation of the George Morrison exhibition will require 2 to 3 days and additional personnel. Personnel will be on hand at the Carnegie Center to help hang the paintings. I will write, design, and produce the labels and gallery guide for the exhibition.

Because this exhibit will appeal to a large audience, it will be important to get the word out. Advertising will be done through several outlets. Postcard mailings will be sent out to members of the Floyd County Historical Society and Carnegie Center's mailing lists, in addition to those selected from the Hite Art 
Institute's mailing list. Prior to the exhibition, I will design and post posters in public buildings. These locations will include public libraries, historic sites, coffee shops and schools in the Southern Indiana and Louisville area. Finally, a press release will be sent out to the local and regional newspapers regarding the opening reception July 14 . 


\section{Preliminary budget}

The budget will include the following primary expenses.

• Travel.......................................\$100.00

- Advertisement:

- postcard mailings Including postage (1500)....\$760.00

○ posters $(60) \ldots \ldots \ldots \ldots \ldots \ldots \ldots . \ldots 50.00$

○ outside banner..................\$300.00

- Installation: personnel, hanging materials (on site)

• Vinyl Lettering.........................\$ 40.00

• Labels.....................................\$ 50.00

• Gallery Guide............................\$120.00

- Reception: food and drinks...........\$400.00

- Other (framed poster for Generations, etc.) \$50.00

Total.....................\$1870.00 
IV. Proposed schedule

December

- Conduct preliminary research on George Morrison

- Meet with David Barksdale, President Floyd County Historical Society

- Contact known individuals with paintings

- Send letters

- Follow up phone calls

- Contact Institutions with paintings and those that might have paintings in area

- Phone calls (Scribner House, etc.)

- Meet with someone at New Albany Public Library to view their paintings

January

- Continue locating artwork

\section{February}

- Wrap up locating artwork

- Complete list of paintings to be included in exhibit

- Begin research on portrait painting for Gallery Guide

\section{March}

- Research Individuals in paintings for labels

- Continue research on portrait paintings

- Design poster for exhibit

- Print sample for approval 
- Continue research on George Morrison

- Travel to Indiana Historical Society

- Complete George Morrison research

April

- Continue research on individuals in paintings

- Choose painting for mailings (printed by Carnegie Center)

May

- Complete essay on portrait paintings

- Design Gallery Guide

- Complete research on individuals

- Contact individuals and institutions loaning paintings

- Send letter outlining how and when paintings should arrive and check-in process

June

- Write and produce labels for paintings

- Display posters in libraries, historical sites, etc.

- Send out mailings- end of month

- UofL, Carnegie Center, and Historical Society Mailing lists

July

- Produce Gallery Guide

- Receive/Pickup artwork

- Fill out loan information 
- Discuss security issues

- Begin and Complete Installation

- Carnegie Center employee, Buddy, to help

- Arrange for opening night Reception: July 14, 2006

- Food, Drink

\section{August}

- Exhibit take down: August 28, 2006

- Return borrowed items to institutions and individuals (owners either pick up or Carnegie personnel will deliver)

- Analyze results of exhibit evaluation as related to future exhibit planning

- Make research available to interested individuals and institutions (Carnegie Center, Floyd County Historical Society, National Portrait Gallery) 


\section{Pre-exhibit Inventory}

The following is a list of paintings that had known locations and were originally planned for display. However, once I began confirming the paintings that could be obtained from private collections and organizing the exhibit in the gallery space, it was clear that I could not display all of these paintings. I chose to take out several paintings that were regularly on display at the library. Although many of these were impressive examples of George Morrison's work, I felt it was more important to display those that were not normally available to the public.

We also chose not to include the portrait of Margaret Shrader due to the poor condition of the painting.

Those that were not part of the Carnegie Center's exhibit are marked with an asterisk.

Self Portrait, 1843, Collection of the New Albany - Floyd County Free Public Library

Lydia Maynard Morrison, 1886, Collection of the New Albany - Floyd County Free Public Library

Mary Morrison (daughter), n.d., Collection of the New Albany - Floyd County Free Public Library

John Shrader, Sr., n.d., Collection of the Shrader Funeral Home

*Margaret Shrader, n.d, Collection of the Shrader Funeral Home

Dr. William Scribner, 1852, Collection of the Scribner House

Harriet Hale Scribner, 1852, Collection of the Scribner House 
Charles "Little Eddie" Scribner, 1852, Collection of the Scribner House Martin Meekin, c.1850, Collection of Gary and Merrell Hansen

Dora Meekin Boardman, n.d., Collection of Gary and Merrell Hansen Cleon Meekin, c.1850, Collection of Gary and Merrell Hansen John Briggs, n.d., Collection of Nancy Kraft Molnar and Paul F. Kraft, Sr. Mary Briggs, n.d., Collection of Nancy Kraft Molnar and Paul F. Kraft, Sr. George Kraft, 1893, Collection of Generations Funeral Home Mary Kerr (Mrs. Michael Kerr), n.d.

Anna Humphries Weir, n.d., Collection of David and Barbara Cannon John Owen Greene, 1869, Collection of the New Albany - Floyd County Free Public Library

Unidentified Child, 1883, Collection of Rod Lich and Susan Parrett

Emma Dora Townsend, n.d., Collection of Phyllis and Sonny Thomas

View from Spickert Knobs, 1856, Collection of the New Albany - Floyd County Free Public Library

*George Lee Hosea and Pamela Maynard, 1848, Collection of the New Albany -Floyd County Free Public Library

Self Portrait from Mirror, 1855, Collection of the New Albany - Floyd County Free Public Library

Steamboat and Barge at Sunset, n.d., Collection of the Filson Historical Society View of New Albany, 1849, Collection of the New Albany - Floyd County Free Public Library 
*Tommy Williams, n.d., Collection of the New Albany - Floyd County Free Public Library

Ashbel Parsons Willard, 1857, Collection of the Indiana Historical Bureau, State of Indiana, Governors' Portraits Collection

Philip Lightfoot Lee, n.d., Collection of the Filson Historical Society Judge John S. Davis, ca. 1850, Collection of the Cody family *General Alexander Burnett, 1844., Collection of the New Albany - Floyd County Free Public Library

*Margaret Ann Burnett, 1844, Collection of the New Albany - Floyd County Free Public Library

*George Morrison and his Subjects by Orville Carroll, 1974, Collection of the Carnegie Center 


\section{APPENDIX B \\ EXHIBIT RESEARCH AND LOAN FORMS}

\section{National Portrait Gallery Survey Form}

Catalog of American Portraits, CENTER FOR ELECTRONIC RESEARCH AND OUTREACH SERVICES, National Portrait Gallery Smithsonian Institution, P.O. Box 37012, Victor Building, Suite 8300, MRC 973, Washington, DC 20013-7012

Phone: (202) 275-1840 Fax: (202) 275-1907 Email: npgresearch@npg.si.edu NPG URL: www.npg.si.edu

OWNER ACCESSION NO.:

SYSTEM ID NO:

$\operatorname{TITLE}(\mathbf{s})$ :

SITTER(s) with life dates:

BIOGRAPHICAL NOTES: (include place of birth and death, if known, as well as occupation or distinction)

SITTER ATTRIBUTES:

infant/child/adolescent/adult/elderly/undeterm Head/bust/waist/knee/full/undeterm

L profile/L 3/4/front full/R 3/4/R profile

Standing/seated/equestrian/recumbe nt/undeterm/other:

Portrait from: Life/possibly/replica/copy/cast/from photo/fictitious/unknown/other: ARTIST(s) with life dates: 
SECONDARY ARTIST(S): (e.g. "Copy after" or "Other attribution")

EXECUTION DATE:

Place:

CLASSIFICATION:

painting/miniature/drawing/silhouette/sculpture/medal/daguerreotype/other:

MEDIUM: oil/watercolor/pastel/chalk/charcoal/pencil/ink/marble/plaster/bronze/other:

SUPPORT: canvas/linen/wood panel/ivory/glass/paper/masonite/canvasboard/other:

SHAPE: rectangular/square/circular/oval/irregular/other:

DIMENSIONS: Height

Width

Depth

Accurate/estimate

PART MEASURED: sight/stretcher/panel/frame/sheet/withbase/withoutbase/unknown/other:

ARTIST'S INSCRIPTIONS:[ ] not signed [ ] no visible signature [ ] not dated [ ] no visible date

OTHER INSCRIPTIONS:

CURRENT OWNER:

OWNER ADDRESS:

OTHER LOCATION:

ACQUISITION METHOD:

Gift/Bequest/Purchase/Exchange/Transfer/Commission/Inherited/ Other:

ACQUISITION SOURCE:

ACQUISITION DATE:

CREDIT LINE:

PROVENANCE:

PORTRAIT DESCRIPTION:

HAIR: brown/blond/black/red/gray/white/other: EYES: brown/blue/green/other:

CLOTHING: 
OBJECTS:

SETTING:

PORTRAIT NOTES:

CONDITION AT TIME OF SURVEY: excellent/good/fair/poor PAST CONSERVATION WORK:

EXHIBITIONS/BIBLIOGRAPHIC REFERENCES (attach extra sheet if necessary):

PHOTOGRAPHY: b\&w/color/digital image/snapshot/polaroid/slide/transparency/none available/other:

PHOTOGRAPHER: CAP/NPG/FARL/owner/other:

NEGATIVE NO:

SOURCE OF DATA:

CATALOGER AND DATE: 


\section{Terms of Loan Agreement}

\section{Terms of Loan Agreement}

1. It is understood that the objects in this loan will remain in the condition received and will not be repaired, restored, cleaned, or altered in any way. The condition is understood to be as stated on the condition form.

2. All damage to objects at any point in this loan from the out date until returned will be reported to the donor immediately.

3. The objects may not be lent to a third party.

4. The objects may be photographed only with the permission of the donor. The borrower agrees that the photographs taken of this loan will be used only for the purpose stated on this form and only for the number of times stated. The donor will receive a copy of all photographs for record purposes. All publications of photographs of items in this loan will bear a credit line acknowledging that the objects are the property of the donor.

5. The borrower is responsible for packing, transportation, insurance, and all other factors of transporting the loan, unless otherwise stated.

6 . The donor may require proof of insurance, may wish to have its name on the policy, and may wish to receive a copy of the insurance policy.

7. The borrower agrees to use the loan only for the purposes stated on the form.

Borrower hereby acknowledges receipt of the object(s) listed on the attached page(s). The undersigned assumes full responsibility for the objects subject to the conditions printed above until their return.

I have read and accept the above loan conditions

Approved and Released by:

Donor

Date

Loan returned and accepted by:

Donor

Date 
III. Condition Report form

\section{CONDITION REPORT}

Artist/Lender Name:

Title:

Medium:

Frame around piece (circle one): wood metal none other:

If framed, frame is: $\mathrm{OK}$ damaged

If damaged, indicate type and location:

Cover over piece: glass Plexiglas none other:

If covered, cover over piece is: OK damaged

If damaged, indicate type and location:

Hanging apparatus: $\mathrm{OK}$ needs replacing

Artwork condition - includes stand, mat, etc.: $\quad$ OK damaged

If damaged, indicate type and location:

Any special instructions:

Examination performed by:

$\underline{\text { Staff (sign \& date) }}$

Artist/Lender (sign-in and date)

Artist/Lender (sign-out and date)
Date of Work:

Daytime Phone \#:

Price: 


\section{APPENDIX C \\ EXHIBITION TEXT}

\section{Introductory text}

The following text gives the reader a brief biographical introduction to George Morrison and his success as a portrait-painter in New Albany and the surrounding areas. The rest of the exhibit text will focus on aspects of the portrait-painting genre presented in Morrison's paintings, but I first wanted the visitors to understand who George Morrison was and why his paintings are significant.

\section{George Morrison (1820-1893): New Albany's Portrait Painter}

George Washington Morrison worked as New Albany's primary professional artist during a time when portraiture was popular among the elite. Many of New Albany's leading citizens commissioned his paintings. In addition, Morrison documented the physical environment by painting landscapes of the New Albany and Ohio Valley region.

Born in Baltimore, Maryland, George Morrison moved to New Albany at the age of 20. After establishing his business as a portrait artist, Morrison purchased a 25-acre site in Silver Hills where he lived with his wife Lydia Maynard, a native of New Albany, and their children. George Morrison lived and worked in New Albany until his death in 1893. 
During his time in Indiana, Morrison painted portraits and landscapes throughout the southern region of the state, including the cities of New Albany, Evansville, Terre Haute, Bedford, Bloomington, as well as Indianapolis. In 1841, only a year after moving to New Albany, Morrison owned a one-room art gallery on High Street, now known as Main Street, where he displayed and sold his paintings. Morrison exhibited at the second State Fair in 1853 and won the first place award of $\$ 15.00$, the equivalent of $\$ 350.00$ today.

George Morrison's portrait paintings not only demonstrate the skill of an accomplished local artist but also document the lives of New Albany's leading citizens and their families during the mid $19^{\text {th }}$ century. 


\section{Label text}

I had an idea regarding the arrangement of the portraits almost from the initial planning stage. I realized that the text panels would be important to divide the exhibit into different sections, keeping the display from being overwhelming.

With the exception of the intro panel, which gives a short biography of George W. Morrison, the text panels focused on aspects of the portrait-painting genre throughout history and more specifically during the mid to late $1800 \mathrm{~s}$. As has been discussed throughout my Museum Methods courses, interpretation is key to any museum exhibit. I wanted the audience to understand why these people were shown in certain clothes and poses, why these were all wealthy white Americans, the reasoning behind painting children in a natural setting with their pets, and the societal influences on landscape paintings. The text panels and the gallery guide essay emphasize George Morrison's place in the larger portrait-painting custom that has evolved from ancient times, placing his portraits and landscapes in a larger context. This background information was necessary for the exhibit to become more than a who's who among New Albany's elite.

In addition to the larger text panels, I felt it important to include some limited biographical information for the subjects of the paintings. These would not only satisfy the visitor's desire to understand who these people were but they reinforce the idea that Morrison's subjects included many of the city's most wealthy and respected members of society. This background on the subjects again illustrates that these portraits were commissioned by the elite citizens of New Albany. 


\section{Symbols of Wealth}

Popularized in ancient times, a portrait serves as a representation of wealth and power. Impressively portraying the subject is the primary purpose of the portrait. Throughout history, members of the upper classes commissioned portrait paintings to serve as status symbols. This interest in portraiture came to America with the early British settlers and continued to develop.

Wealthy Americans sought to associate themselves with the established wealth of the British elite by continuing the tradition of portraiture; therefore, portrait painting became a prosperous business in America during the $19^{\text {th }}$ century. Almost every city could support at least one portrait painter.

Although other artists traveled through New Albany, George Morrison worked as the city's principal portrait painter during this period. Recognized for his skill, Morrison established himself as the city's preferred artist.

\section{Fashion and the Portrait}

The clothing and hairstyles worn by the subject of a portrait reflect the social and economic aspirations as well as cultural values of the person. The fashion worn offers a visual biography of the subject.

Although individuals wanted themselves depicted as well-to-do, it was also important to come across as respectable "god-fearing" members of society. Decorative accessories, such as jewelry and lace, were acceptable but kept to a minimum. An example is the dress of Dora Meekin Boardman who wears a simple lace collar and broach with a very traditional black dress.

Allowed to dress less conservatively, a child's appearance often reflects the affluence of the parents. Cleon Meekin, with curls in her hair, holds a bunch of flowers and wears a formal white dress and gold locket. These decorative details are symbols of the prosperity and social standing of the Meekin family. 


\section{George Morrison's Style}

Artists impose their own ideas and style when interpreting the appearance of an individual. George Morrison gives his subjects a mild, genial appearance despite his detail-oriented, stiff technique.

The painting of Governor Ashbel Willard reflects Morrison's style. Willard stands in a firm pose, addressing the viewer, while his facial expression remains calm and warm. Although many of his subjects appear to confront the viewer, Morrison gives his subjects a tranquil appearance, making his portraits less intimidating and more inviting.

\section{Victorian Era Children}

The childhood mortality rate remained high during the $19^{\text {th }}$ century. Parents commonly commissioned paintings of their children at a young age or "mourning pictures," portraits painted after a child's death. These portraits served as mementos for the parents after a child had reached adulthood or passed away.

Portraits of children were often painted full-length and in a natural setting. Artists frequently depicted children playfully, with a small pet as a symbol of youth and innocence.

These aspects of childhood portraiture reflect the Romantic ideals of nostalgia and sentimentality popularized in the Victorian era. George Morrison's portraits of children reflect society's emerging interest in childhood as a distinct and precious stage of life.

\section{Images of a Changing World}

Although he specialized in portraiture, George Morrison created a number of acclaimed landscape paintings featuring New Albany and the surrounding Ohio Valley region. These landscapes demonstrate society's optimism through the pristine images of steamboats and far-off views of the city. 
The potential of emerging scientific discoveries and the coming age of industrialization inspired Americans during the mid $19^{\text {th }}$ century. George Morrison's paintings clearly conveyed this optimism while also expressing nostalgia for a world that was rapidly changing. His cityscapes are shown from a distance offering a reflective image rather than involving the viewer in the hustle and bustle of everyday life. The use of "soft light" expresses the artist's idealized view of a world quickly fading away.

These nostalgic images are appropriate and predictable during a period of rapid change, when the public felt excitement at the possibilities for the future while at the same time fearful that this change would result in the loss of traditional ways of living.

\section{Scribner family}

The son of Joel Scribner, one of the city's three founding brothers, Dr. William Scribner and his family lived in the city's first frame house located on Main Street. The Scribner House is maintained as a Chapter House and Museum by the Piankeshaw Chapter of the Daughters of the American Revolution.

\section{John Shrader}

John Shrader became a successful and industrious New Albany businessman, owning a furniture making company and a mortuary that is still in operation. In 1840, he married Margaret Smith, an active member of the Wesley M. E. Church. They were married 55 years and had 10 children.

\section{Ashbel Parsons Willard}

Born in New York and educated at Hamilton College, Ashbel P. Willard moved to New Albany in 1845 where he practiced law and became involved in local politics. 
Elected governor of Indiana at the age of 36 , Willard died only four years later, becoming the first Indiana governor to die in office.

\section{Philip Lightfoot Lee}

A native of Bullitt County, Kentucky, Philip Lee served in the Kentucky State Legislature and became Captain of the State Guard during the Civil War. After the war, Lee returned to Bardstown where he practiced law and was elected as Commonwealth Attorney in 1866. 


\section{Gallery guide text}

\section{George Morrison and the Portrait in $19^{\text {th }}$ Century America}

Portraiture has served a documentary purpose throughout history. The earliest forms of portraiture were pre-historic funerary paintings of the dead. Later, the Egyptians believed that a portrait helped ensure immortality for the deceased. During the $16^{\text {th }}$ century kings and queens requested paintings of themselves. These royal portraits served as political propaganda, promoting the individual's political persona and presenting a personified image of the nation. ${ }^{1}$

British patrons continued the tradition of respect for the dead and propaganda by including the portrait in a form of ancestor worship. Elite British families commonly displayed numerous paintings of ancestors throughout their homes, advertising their impressive genealogy. ${ }^{2}$ The interest in portrait painting came to America with the early settlers and continued to develop with later generations.

During the $19^{\text {th }}$ century, portrait painting became an especially prosperous business. Americans experienced increasing economic success and the benefits of urban growth. Nearly every community could support at least one portrait painter. ${ }^{3}$ Prominent members of American society commissioned portraits of themselves and their families, carrying on the British tradition of personal propaganda.

\footnotetext{
${ }^{1}$ Malcolm Warner, Portrait Painting, 5-9.

${ }^{2}$ Robin Simon, The Portrait in Britain and America, 9.

${ }^{3}$ William H. Gerdts, "Natural Aristocrats in a Democracy: 1810-1870," 27.
} 
George Morrison began working as a portrait painter during this period, coming to New Albany in 1840. His success as an artist in the portrait-painting genre suggests that Morrison was both talented and able to produce work that followed the accepted style of the day. George Morrison's paintings help us understand characteristics of the popular portrait painting genre in mid $19^{\text {th }}$ century America.

Although other artists traveled through the area, George Morrison worked as New Albany's principal portrait painter, establishing himself as the city's preferred artist. Many of New Albany's leading citizens commissioned his paintings, including the Scribner, Meekin, Kraft and Shrader families, in addition to political figures such as Indiana Governor Ashbel Willard. Each of these families and individuals experienced economic success and chose to express this by having their portraits painted by Morrison. The portraits painted for these affluent individuals conveyed an image of wealth and prosperity.

This image of success was communicated through the appearance of the individual. While the face is the most significant part of a portrait, clothing and hair occupy much more of the painting. The individual's clothing reflects the social and economic aspirations as well as cultural values of the person, creating a visual biography of the subject. ${ }^{4}$

Although individuals wanted themselves depicted as "well-to-do," it was also important to be seen as respectable "god-fearing" members of society. The portrait of Dora Meekin Boardman reflects this desired image of a wealthy yet respectable woman. Mrs. Boardman wears a decorative lace collar and brooch 
with a traditional black dress. Decorative accessories, such as jewelry and lace, were acceptable but kept to a minimum.

A child was not expected to dress as conservatively as an adult and commonly reflected the affluence of the parents. Morrison's painting of Cleon Meekin depicts the young girl with curls in her hair wearing a formal white dress and gold locket. These decorative details are symbols of the prosperity and social standing of the Meekin family. The clothing worn by these individuals conforms to the propagandistic tradition of the portrait.

In addition to representing the family's success, portraits of children occupied a special place in the hearts and homes of their parents and relatives. The childhood mortality rate remained high during the $19^{\text {th }}$ century prompting parents to commission paintings of their children at a young age or "mourning pictures," portraits painted after a child's death. These portraits served as mementos for the parents after a child had reached adulthood or passed away.

Portraits of children were often painted full-length and in a natural setting. Artists frequently depicted children playfully, with a small pet as a symbol of youth and innocence, adding to the sentimental nature of these paintings. ${ }^{5}$ These aspects of childhood portraiture reflect the Romantic ideals of nostalgia and sentimentality popularized in the Victorian era. Those who could afford portrait paintings could afford to appreciate their children as more than another member of the family work force. George Morrison's portraits of children convey society's emerging interest in childhood as a distinct and precious stage of life.

\footnotetext{
${ }_{5}^{4}$ Wayne Craven, Colonial American Portraiture, 29.

5 "Seen But Not Heard: Images of Children from the Collection of the Boston Athenæum."
} 
Each of George Morrison's portraits reflects his unique style and interpretation of his subjects. Despite his detail-oriented technique, Morrison gives individuals a mild, genial appearance. One of his most significant and valued paintings is a portrait of Governor Ashbel Willard painted in 1857 and normally displayed at the Indiana Statehouse in a collection of Governors' paintings. Morrison depicts Willard standing in a firm pose, addressing the viewer, with a calm and warm expression. ${ }^{6}$ Although many of his subjects appear to confront the viewer, Morrison instills individuals with a tranquil appearance, making his portraits appear less intimidating and more inviting.

Although Morrison specialized in portraiture, he created a number of acclaimed landscape paintings. These views of New Albany and the surrounding Ohio Valley region reveal society's ambivalent feelings of optimism and yet apprehension for the future. George Morrison's use of soft light and distance in his landscapes offers a reflective image rather than involving the viewer in the hustle and bustle of everyday life. These nostalgic images are appropriate during a period of rapid change when Americans were inspired by the potential of emerging scientific discoveries and coming age of industrialization but fearful of these changes as well.

The work of George Morrison helps us understand the political and social values held in $19^{\text {th }}$ century New Albany. From conveying success and identity through adult portraiture giving the viewer a sense of who this person was to expressing feelings of nostalgia with landscapes and portraits of children, these paintings are best understood as reflections of life in America during the mid-

\footnotetext{
${ }^{6}$ Wilbur D. Peat, Portraits and Painters of the Governors of Indiana 1800-1978, 36.
} 
1800s. Although portraiture has evolved with the widespread use of the camera and changing artistic movements, portraits remain a popular form of art and a means to present a desired image to the world. Morrison's paintings reveal the continuing adaptation of the portrait-painting genre to satisfy the needs of its subjects and their society in addition to demonstrating the political and technical skills of an accomplished local artist. 
IV. Exhibition checklist

Self Portrait, 1843, Collection of the New Albany - Floyd County Free Public Library

Lydia Maynard Morrison, 1886, Collection of the New Albany - Floyd County Free Public Library

Mary Morrison (daughter), n.d., Collection of the New Albany - Floyd County Free Public Library

John Briggs, n.d., Collection of Nancy Kraft Molnar and Paul F. Kraft, Sr.

Mary Briggs, n.d., Collection of Nancy Kraft Molnar and Paul F. Kraft, Sr.

Dr. William Scribner, 1852, Collection of the Scribner House

Harriet Hale Scribner, 1852, Collection of the Scribner House

Charles "Little Eddie" Scribner, 1852, Collection of the Scribner House

Martin Meekin, c.1850, Collection of Gary and Merrell Hansen

Dora Meekin Boardman, n.d., Collection of Gary and Merrell Hansen

Cleon Meekin, c.1850, Collection of Gary and Merrell Hansen

John Shrader, Sr., n.d., Collection of the Shrader Funeral Home

Judge John S. Davis, ca. 1850, Collection of the Cody family

George Kraft, 1893, Collection of Generations Funeral Home

Ashbel Parsons Willard, 1857, Collection of the Indiana Historical Bureau,

State of Indiana, Governors' Portraits Collection

Mary Kerr (Mrs. Michael Kerr), n.d.

Philip Lightfoot Lee, n.d., Collection of the Filson Historical Society

Anna Humphries Weir, n.d., Collection of David and Barbara Cannon 
John Owen Greene, 1869, Collection of the New Albany - Floyd County Free

Public Library

Unidentified Child, 1883, Collection of Rod Lich and Susan Parrett

Emma Dora Townsend, n.d., Collection of Phyllis and Sonny Thomas

Self Portrait from Mirror, 1855, Collection of the New Albany - Floyd County

Free Public Library

View of New Albany, 1849, Collection of the New Albany - Floyd County Free

Public Library

Steamboat and Barge at Sunset, n.d., Collection of the Filson Historical Society

View from Spickert Knobs, 1856, Collection of the New Albany - Floyd County

Free Public Library 


\section{CURRICULUM VITAE}

NAME: Brenna Liane White

ADDRESS: 8935 Old Vincennes Rd.

Greenville, IN 47124

DOB: Louisville, Kentucky - September 16, 1982

EDUCATION

\& TRAINING: Collections Research Volunteer

Louisville Science Center

2004

B.A., History

Indiana University

2000-2004

Hite Assistantship

University of Louisville

2005

Collections Intern

Carnegie Center for Art and History

2005-2006

Museum Clerical Assistant

Callahan Museum of the American Printing House

for the Blind

2005-present 


\section{ADDENDUM A \\ PROMOTIONAL MATERIALS}

\section{Press Release}

May 18, 2006

FOR IMMEDIATE RELEASE

Contact: $\quad$ Laura Wilkins 812-944-7336

Iwilkins@carnegiecenter.org

\section{Carnegie Center Announces New Exhibit, “George Morrison (1820-1893): New Albany's Portrait Painter" July 14-August 26, 2006 \\ Opening Reception Friday July 14, 6-8 pm}

The Carnegie Center for Art and History in New Albany, Indiana, is pleased to announce the opening of a new exhibit, “George Morrison (1820-1893): New Albany's Portrait Painter," which will present portraits and landscape paintings by the $19^{\text {th }}$ century artist. The exhibit provides an introduction to characteristics of the portrait-painting genre, popular during the mid 1800s, as presented through Morrison's paintings.

Throughout history, portraiture has served as a status symbol among the elite, becoming an especially prosperous business during the $19^{\text {th }}$ century. George Morrison worked as New Albany's principal portrait painter during this period.

Morrison moved to New Albany in 1840 and established himself as the region's primary portrait painter during a time when portraiture was popular among the elite. Many of New Albany's leading citizens commissioned his paintings, including the Scribner, Meekin, and Shrader families whose paintings will be on display. A centerpiece of the exhibit is a portrait of Governor Ashbel P. Willard, which is currently 
on display at the Indiana State House in a collection of Governors' paintings. George Morrison's portrait paintings not only demonstrate the skill of an accomplished local artist but also document the lives of New Albany's leading citizens and their families during the mid $19^{\text {th }}$ century. The exhibit includes landscapes of the Ohio Valley region painted by George Morrison, including a "portrait" of New Albany completed in 1849. The exhibit will be on display July 14 - August 26, 2006.

There will be an opening reception for this exhibit on Friday, July 14, from 6 to $8 \mathrm{pm}$. This event is free and open to the public.

The Carnegie Center for Art and History, a department of the New Albany-Floyd County Public Library, is a contemporary art gallery and history museum that offers a full schedule of changing exhibitions and other educational programs. The Carnegie Center is also home to two permanent exhibits: Ordinary People, Extraordinary Courage, an interactive multimedia exhibit on the Underground Railroad, and Grandpa Makes $A$ Scene: The Yenawine Dioramas, a hand-carved, animated display of life in turn of the century Georgetown, Indiana. The Carnegie Center is open Tuesday through Saturday, 10:00 am-5:30 pm, and is located at 201 East Spring Street in historic downtown New Albany, Indiana. The Carnegie Center for Art and History is fully accessible. Admission is free. 


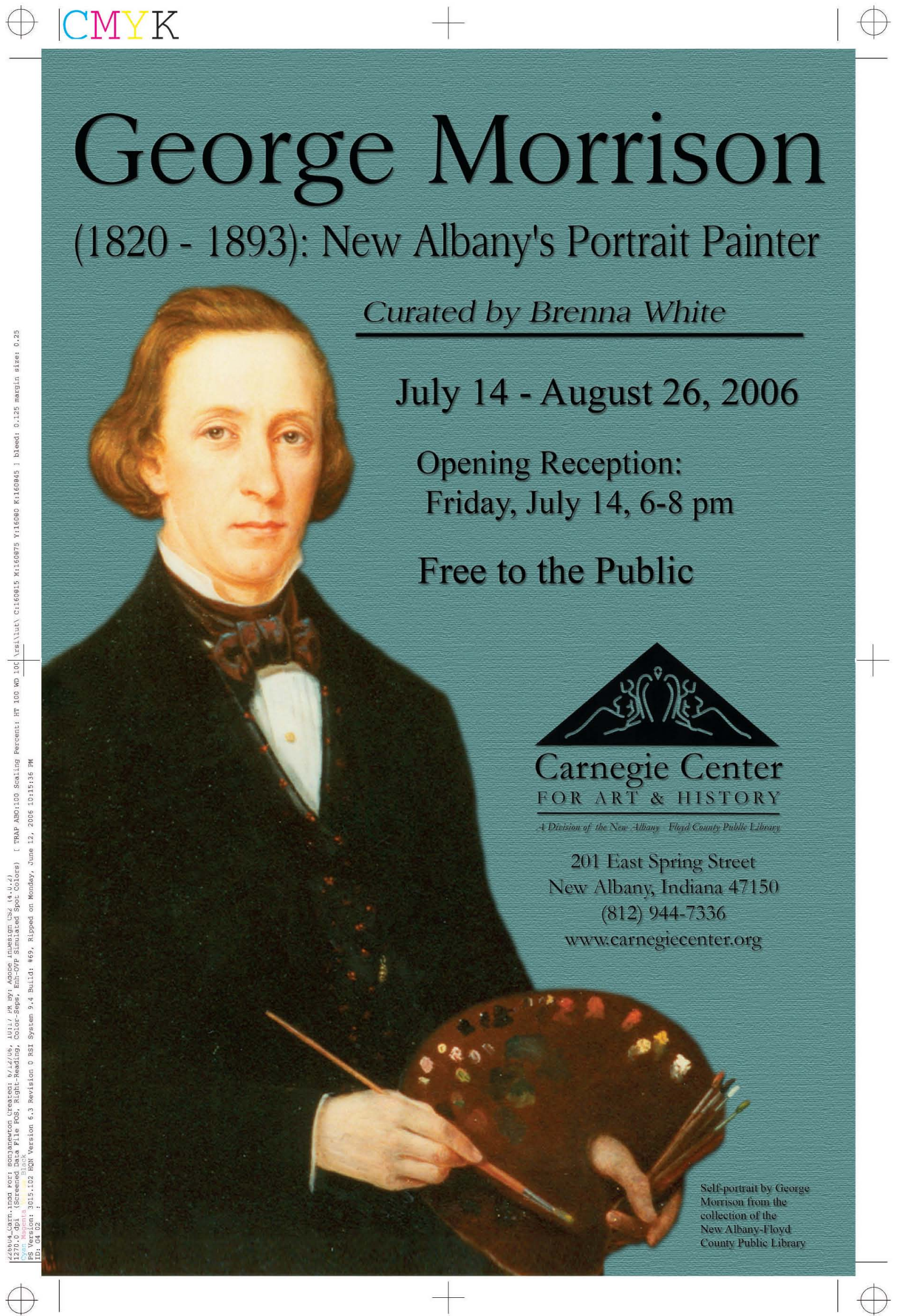




\section{George Morrison}

New Albany's Portrait Painter 1820 -1893
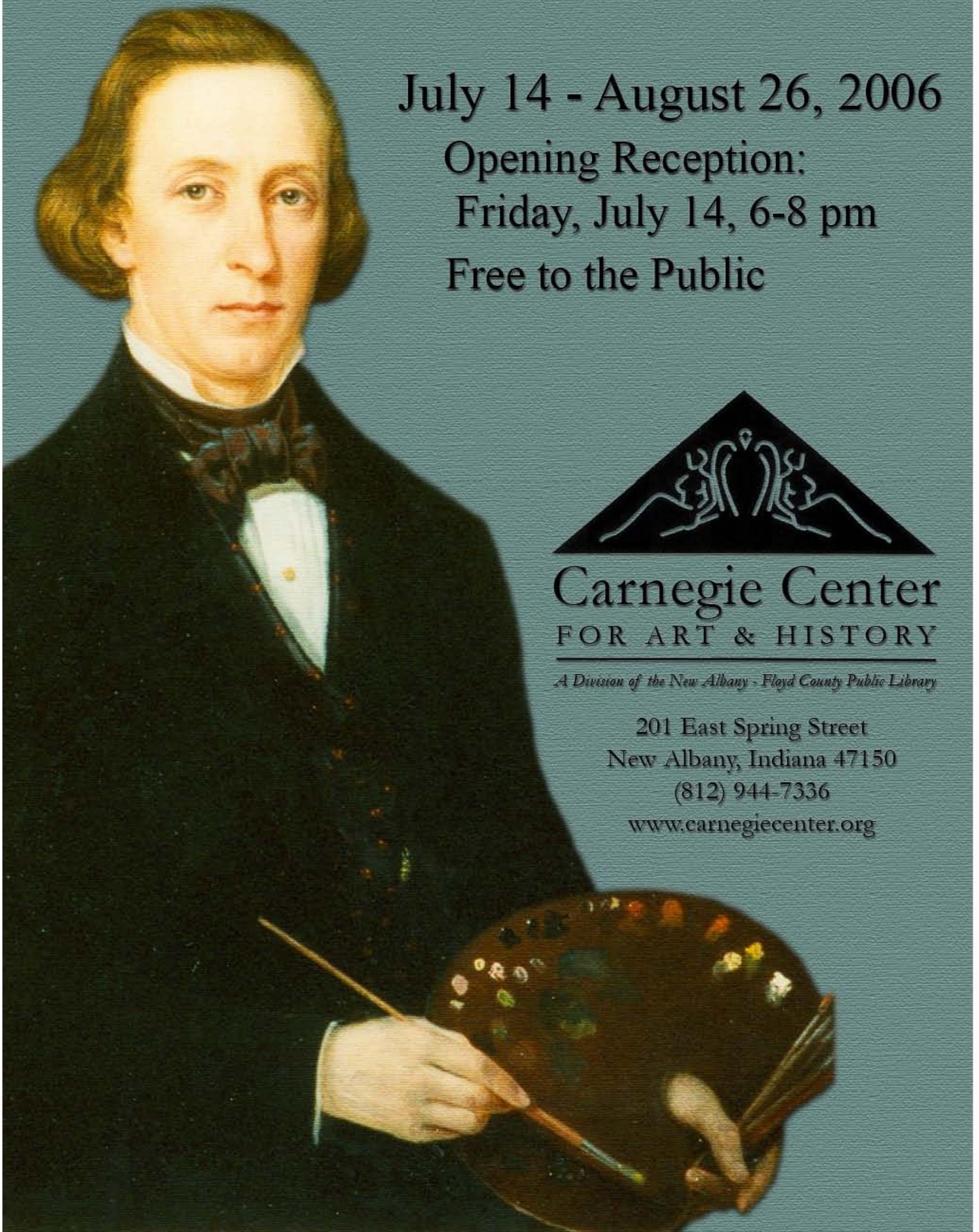
and the surrounding Ohio Valley region reveal society's ambivalent feelings of optimism and yet apprehenston for the future. George Morrison's us: of soft light and distance in his landscapes offers a reflective image rather than involving the viewer in the hustle and bustle of everyday life. These nostalgic images are approprate during a period of rapid change when Americans were inspired by the potential of emerging scientific discoveries anc coming age of industrialization but feartul of these changes as well.

The work of George Mortison helps us understand the political and social values held in $19^{\text {th }}$ century New Albany. From conveying success and identity through adult portraiture, giving the viewer a sense of who this person was, to expressing feelings of nostalgia with landscapes and portraits of children, these paintings are best understood as reflections of life in America during the mid1800s. Although portraiture has evolved with the widespread use of the camera and changing artistic movements, portraits remain a popular form of art and a means to present a desired image to the world. Morrison's paintings reveal the continuing adaptation of the portrait-painting gente to satisfy the needs of its subjects and their society in addition to demonstrating the political and technical skills of an accomplished local artist.

\section{Endnotes}

Malcolm Wamer, Portrait Painting 5.9

${ }^{2}$ Robin Simon, The Ponreaic in Brigin and Americas

Willam H Gerdes, "Natural Artstocrats in a Democtacy. 1810-1870" 27

"Wayte Craven, Colonial American Pootraiture 20.0

"Seen Bur Not Heard. Images of Childen firm the Colle

aWillour D. Peat, Portrails and Painters of the Governors of Indiana 1800-1978, 36.

\section{Bibliography}

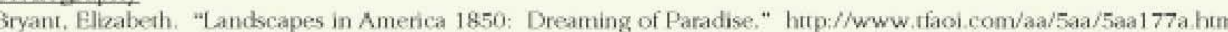
Craven, Wayne Colonial American Portrature, Cambridge: Cambridge Universiry Press, 1986

Gerdis, William H "Nanuml Avistocrats in a Democracy. 1810-1870" Quick 27.60

пр: $/$ / wew

Johns, Parbar "Landsapes in Americe 1850-1890"

Peat, Wilbur D Pioneer Painters of Indiana, Indianapolis: Art Association of Indianapolls, Indiana, 1054 Peat, Willbur D. Portiais and Painters of the Governors of Indtana 1800-1978, Indianapolis: Indiana Historical Sociery, 1978.

Michael, ed American Porraiture in the Grand Manner. 1720-1920. Los Angeles: Los Angeles County Museum of Arr, 198

Quick. Michaed. "Princely Images in the Wilderness: 1720-1755." Ouick $10-20$

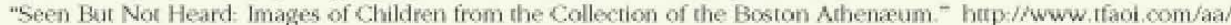
5aa/5aa283.htm

Simon, Robin. The Porririr in Briain and America, Boston. G.K. Hall and Co, 1907 Warner Malcolm. Portrati Painting Onford Phaidon Pregs Limised 1979

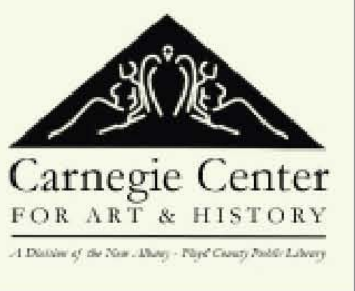

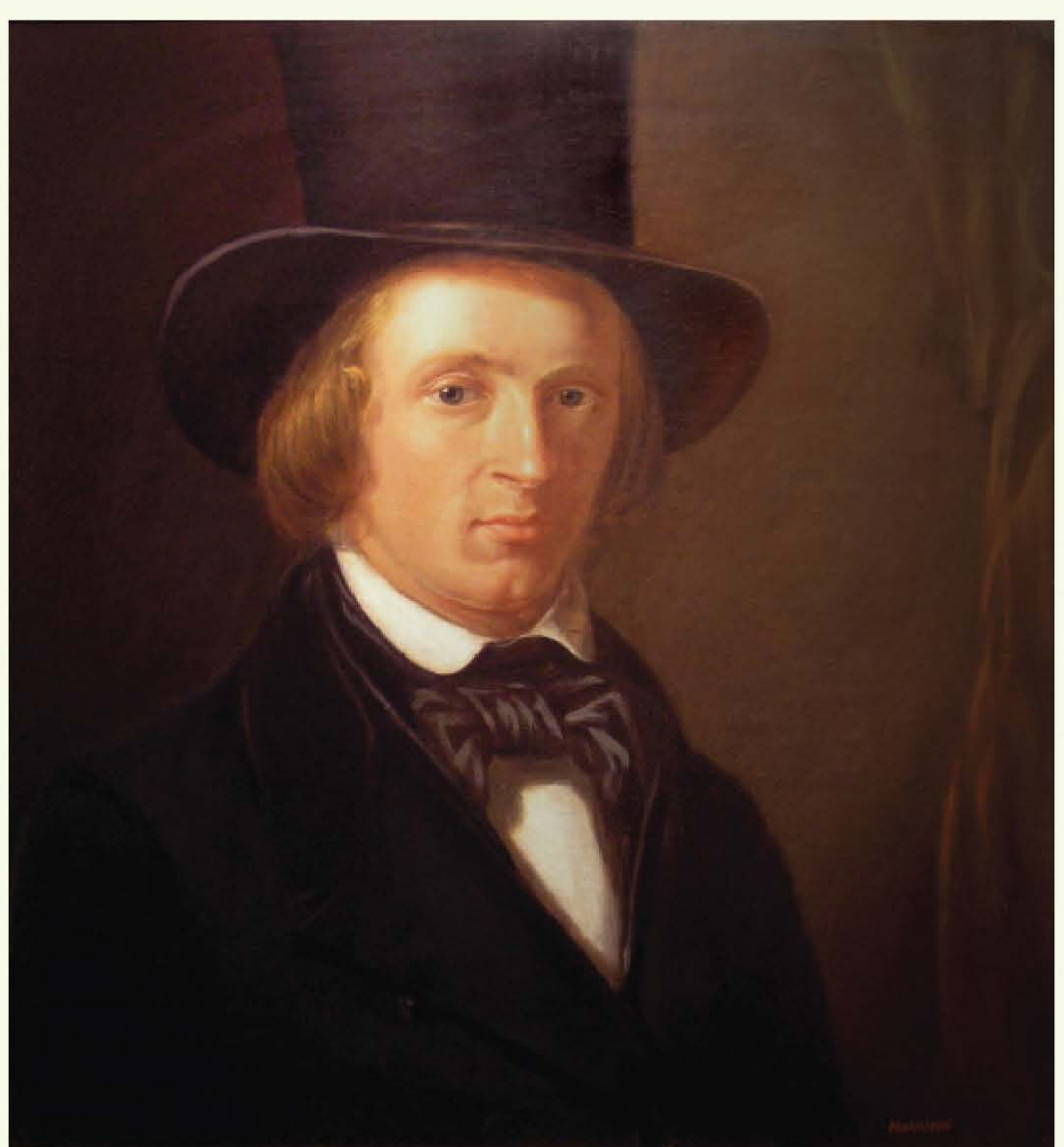

\section{George Morrison} (1820-1893): New Albany's Portrait Painter

Curated by Brenna White 


\section{George Morrison and the Portrait} in 19 th Century America

Portraiture has served a documentary purpose throughout history. The earliest forms of portraiture were pre-historic funerary paintings of the dead. Later, the Egyptians believed that a portrait helped ensure immortality for the deceased. During the $16^{\text {th }}$ century kings and queens requested paintings of themselves. These toyal portraits served as political propaganda, promoting the individual's political persona and presenting a personified image of the nation

British patrons continued the tradition of respect for the dead and propaganda by including the portrait in a form of ancestor worship. Eltte British families commonly displayed numerous paintings of ancestors throughout their homes. advertising their impressive genealogy. ${ }^{2}$ The interest in portrait painting came to America with the early settlers and continued to develop with late generations

During the $19^{\text {th }}$ century, portrait painting became an especially prosperous business. Americans experienced increasing economic success and the benefits of urban growth. Nearly every community could support at least one portra painter. ${ }^{3}$ Prominent members of American sociery commissioned portraits of themselves and their families, carrying on the British tradition of person propaganda

George Morrison began working as a portrait painter during this period, coming to New Albany in 1840. His success as an artist in the portraitpainting genre suggess that Morrison was both talented and able to produce work that followed the accepted style of the day. George Morrison's paintings help us understand characteristics of the popular portrait painting genre in mid $19^{\text {th }}$ century America.

Although other artists traveled through the area, George Morrison worked as New Albany"

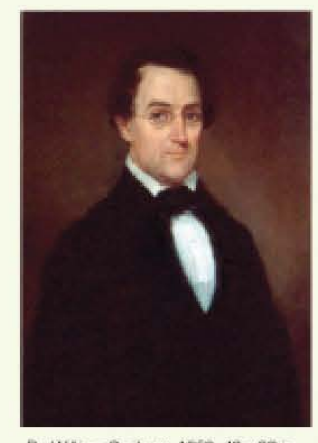

Collection of the Sintrere Hous principal portrait painter establishing himself

as the city's preferred artist. Many of New

Albany"s leading citizens commissioned his paintings, including the Scribner, Meekin, Kraf and Shrader families, in addition to political figures such as Indiand Governor Ashbel Willard. Each of these fanilies and individuals experienced economic success and chose to express this by having their portraits painted by Morrison. The portraits painted for these affluent individuals conveyed an image of wealth and prosperity.

This inage of success was communicated through the appearance of the individual. While the face is the most significant part of a portrait, clothing and hair occupy much more of the painting. The individual's clothing reflects the social and economic spirations as well as cultural values of the person, creating a visual biography of the subject. ${ }^{4}$

Although individuals wanted themselves deptcted as "well-to-do," it was also important to be seen as respectable "god-fearing" nembers of society. The portrait of Dora Meekin Boardman reflects this desired image of a wealthy yet respectable woman. Mrs. Boardman wears a decotative lacé collar and brooch with a traditional

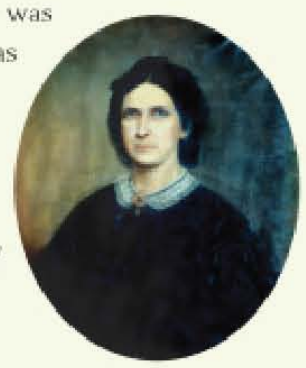

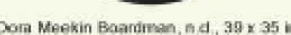

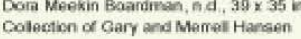
black dress. Decorative accessories, such as jewelry and lace, were acceptable but kept to a minimum.

A child was not expected to dress as conservatively as an adult and commonly reflected

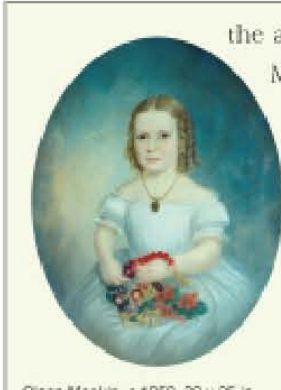

affluence of the parents. Morrison's painting of Cleon Meekin depicts the youn girl with curls in her hair wearing a formal white dress and gold locker

These decorative details are symbols of the prosperity and social standing of the Meekin family, The clothing worn by these individuals conforms to he propagandistic tradition of the portrait.

In addition to representing the family's success, portraits of children cocupied a snecial place in the hearts and homes of their parents and relatives. The childhood mortality rate remained high during the $19^{\text {th }}$ century prompting parents to commission paintings of their children at a young age or "mourning pictures," portraits painted after child's death. These portraits served as mementos for the parents after a child had reached adulthoon or passed away.

Portraits of children were often painted fult. length and in a natural setting. Artiss frequently depicted children playfully, with a small pet as a symbol of youth and innocence. adding to the sentimental nature of thest paintings. These aspects of childhood portraiture reflect the Romantic ideals of nostalgia and sentimentality popularized in

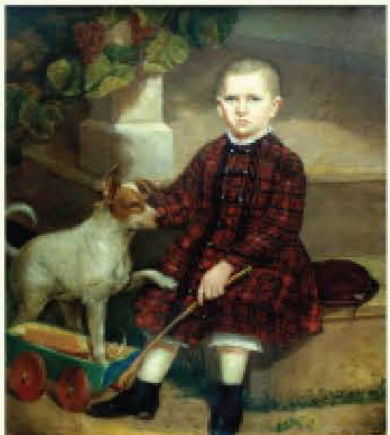

the Victorian era. Those who could afford portrai paintings could afford to appreciate their children as more than another member of the family work force, George Morrison's portraits of children convey society's emerging interest in childhood as a distinct and precious stage of life

Each of George Morrison's portraits reflects his unique style and interpretation of his subjects. Sespite his detail-oriented technique, Morrison gives individuals a mild, genial appearance. One of his most significant and valued paintings is a portrait of Govemor Ashbel Willard painted in

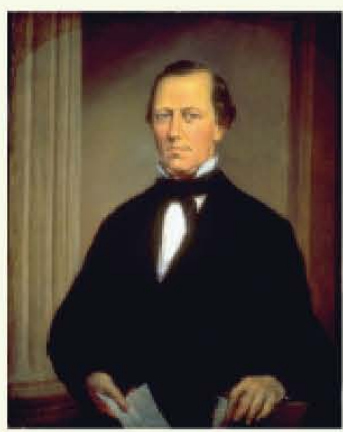
857 and normally displayed at the Indiana Statehouse in a collection of Governors' paintings. Morrison depicts

Willard standing in irm pose, addressing the viewer, with calm and warm expression.

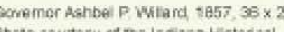
Although many of Bunau 5 his subjects appear to confront the

viewer, Morrison instills individuals with a tranquil ppearance, making his portraits appear les intimidating and more inviting

Although Morrison specialized in portraiture, he created a number of acclaimed andscape paintings. These views of New Albany

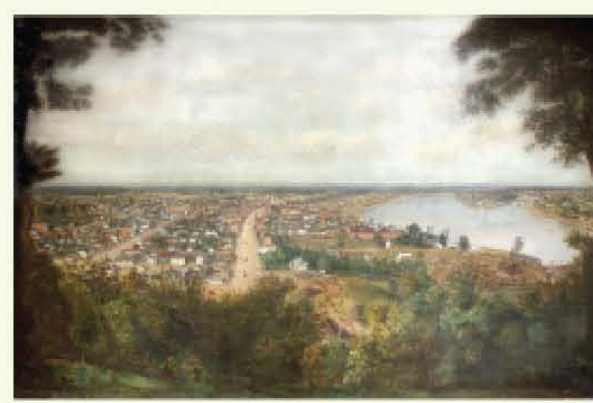

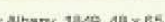

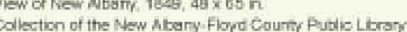


Brenna L. White

8935 Old Vincennes Rd.

Greenville, IN 47124

October 13, 2006

Pamela J. Bennett, Director

Indiana Historical Bureau

140 North Senate Avenue

Indianapolis, IN 46204

Dear Ms. Bennett,

I am completing a Masters thesis at the University of Louisville entitled "George Morrison, New Albany, and the Portrait in $19^{\text {th }}$ Century America" I would like your permission to reprint in my thesis the following:

Photo of Ashbel Parsons Willard portrait painted by George W. Morrison to be used in Gallery Guide as an example of Morrison's portraiture. Photo will be credited to to the Indiana Historical Bureau, State of Indiana, Governors' Portraits Collection.

The requested permission extends to any future revisions and editions of my thesis, including non-exclusive world rights in all languages, and to the prospective publication of my thesis by UMI. These rights will in no way restrict republication of the material in any other form by you or by others authorized by you. Your signing of this letter will also confirm that you own [or your company owns] the copyright to the above-described material.

If these arrangements meet with your approval, please sign this letter where indicated below and return it to me in the enclosed return envelope. Thank you very much.

Sincerely,

Brenna L. White

PERMISSION GRANTED FOR THE USE REQUESTED ABOVE:

Pamela J. Bennett, Director

Indiana Historical Bureau

Date: 


\section{ADDENDUM B EXHIBIT DOCUMENTATION}

The following pages are photos of the George Morrison (1820-1893): New Albany's Portrait Painter exhibit which was on display at the Carnegie Center for Art and History from July 14 -August 26,2006 . These photos were taken by myself during the last week of display.

The first set of images are photos of each individual painting in the exhibit. They are in the order they were displayed, beginning in the right gallery and around into the left gallery.

The second and third sets of images are photos taken of the galleries during the Morrison exhibit, first the right and then the left gallery. These are intended to give an overall view of how the paintings were arranged. 


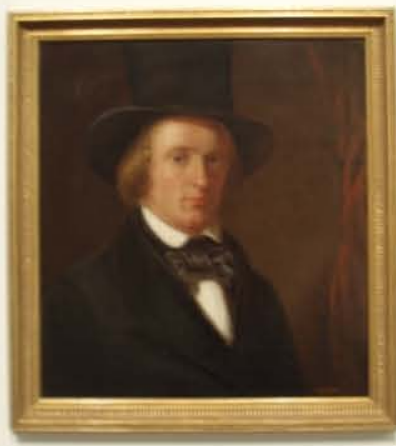

1. George Morrison

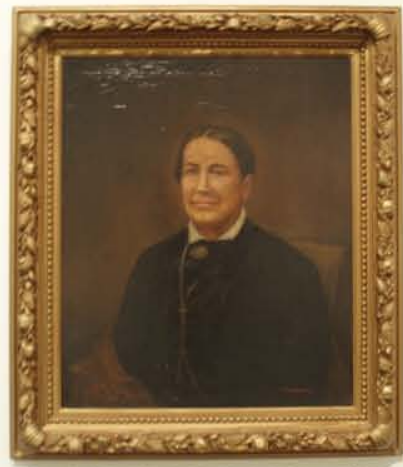

5. Mary Briggs

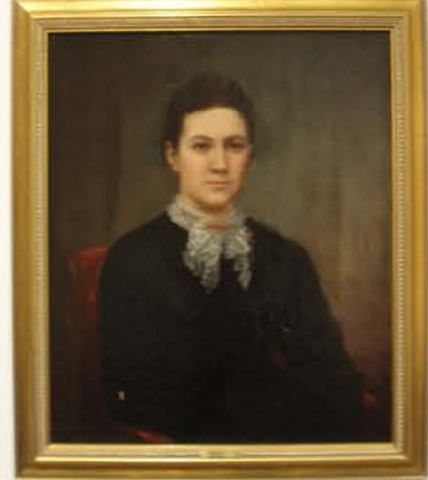

2. Lydia Maynard Morrison

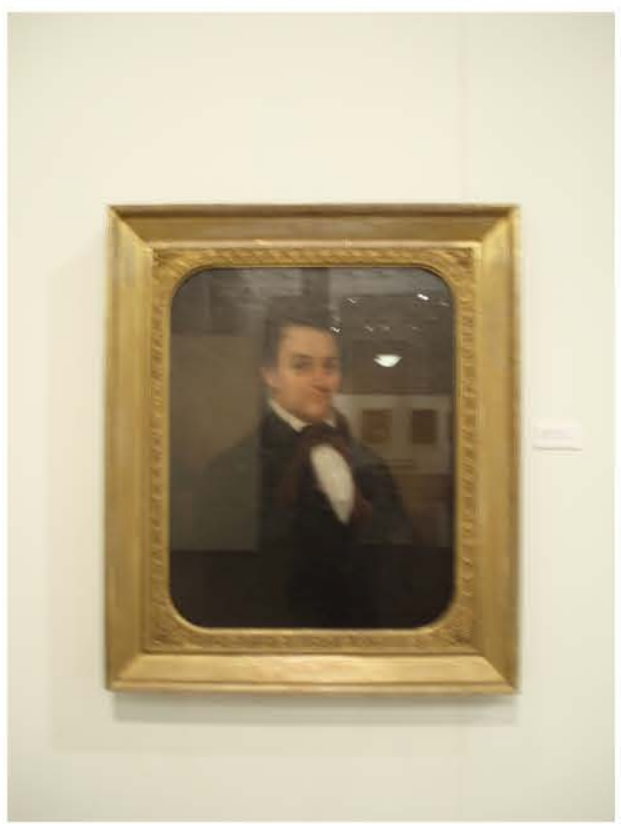

6. William Scribner

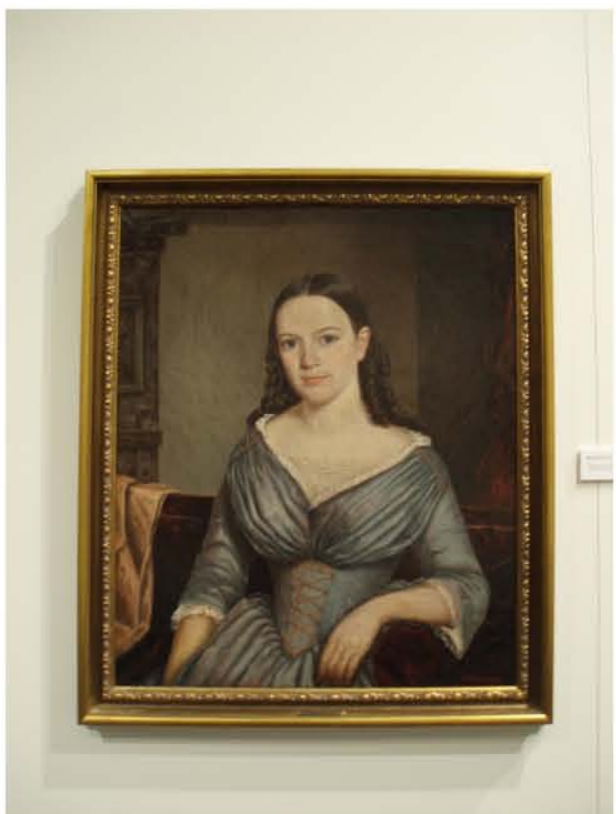

3. Mary Morrison

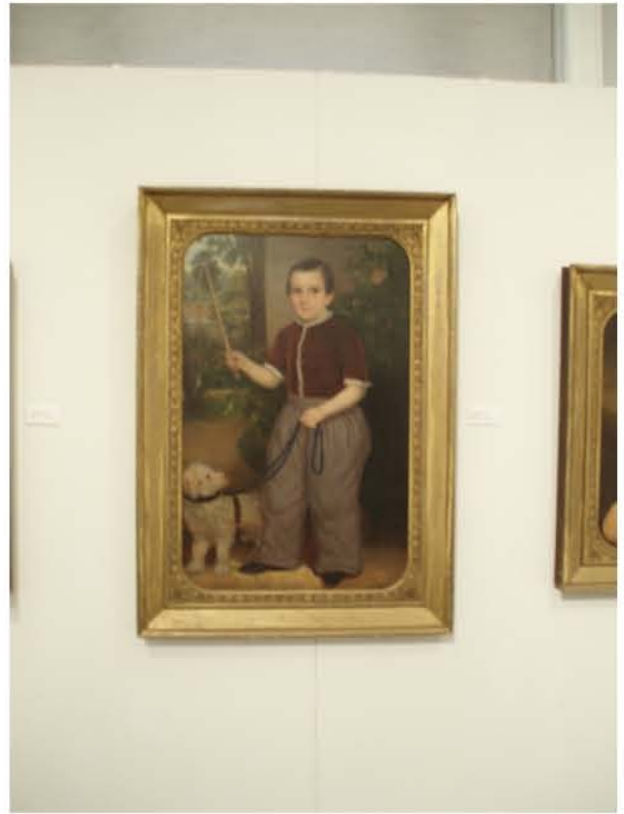

7. "Little Eddie" Scribner

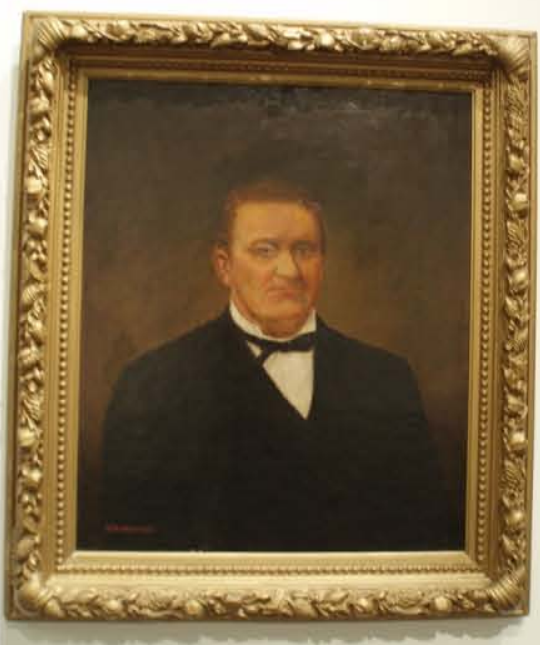

4. John Briggs

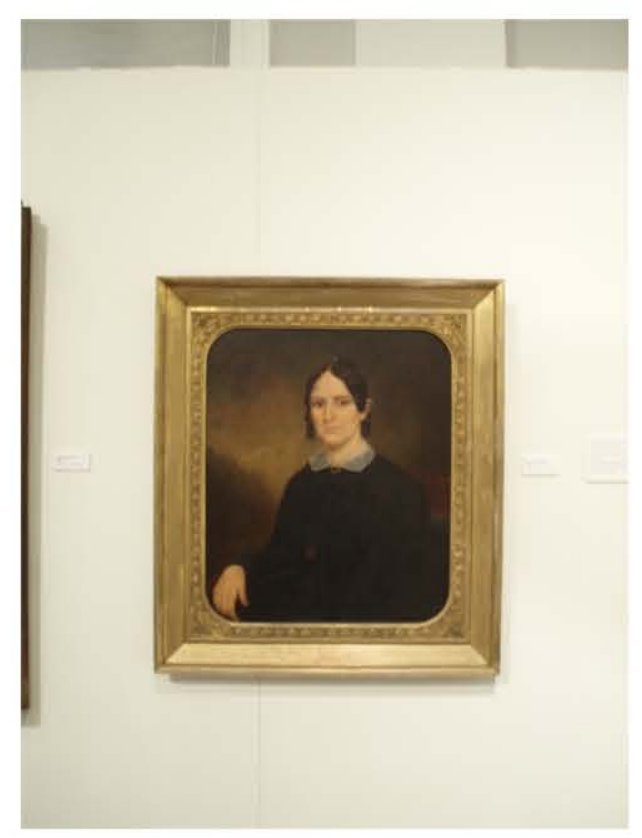

8. Harriet Hale Scribner 


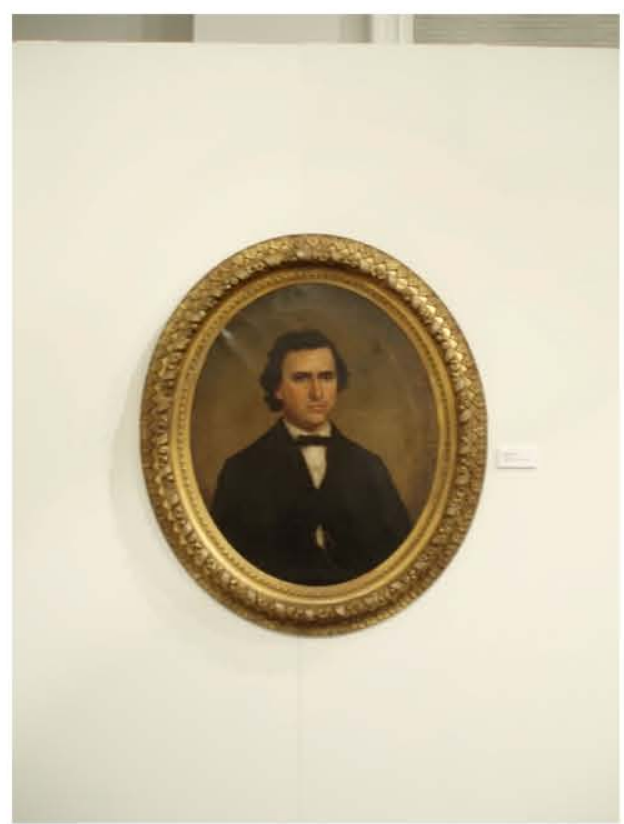

9. Martin Meekin

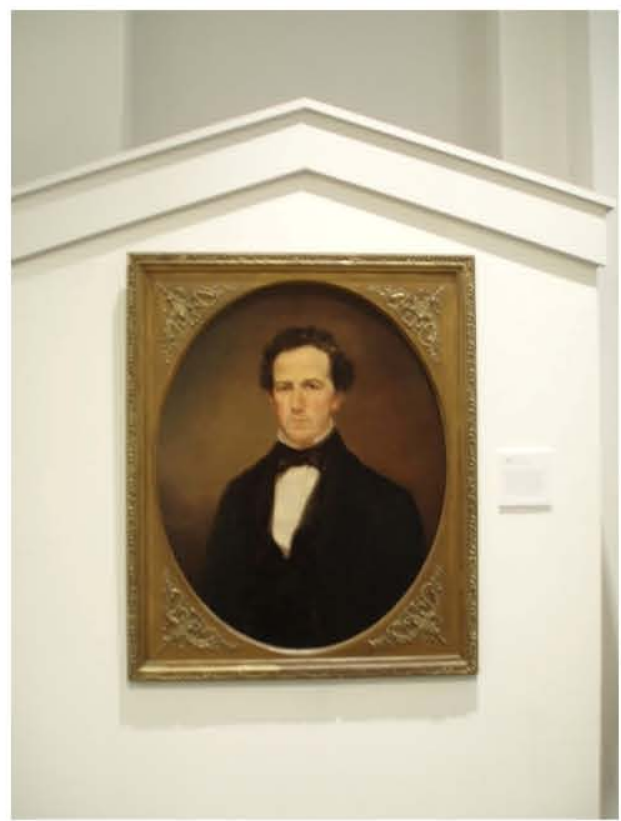

13. Judge John Davis

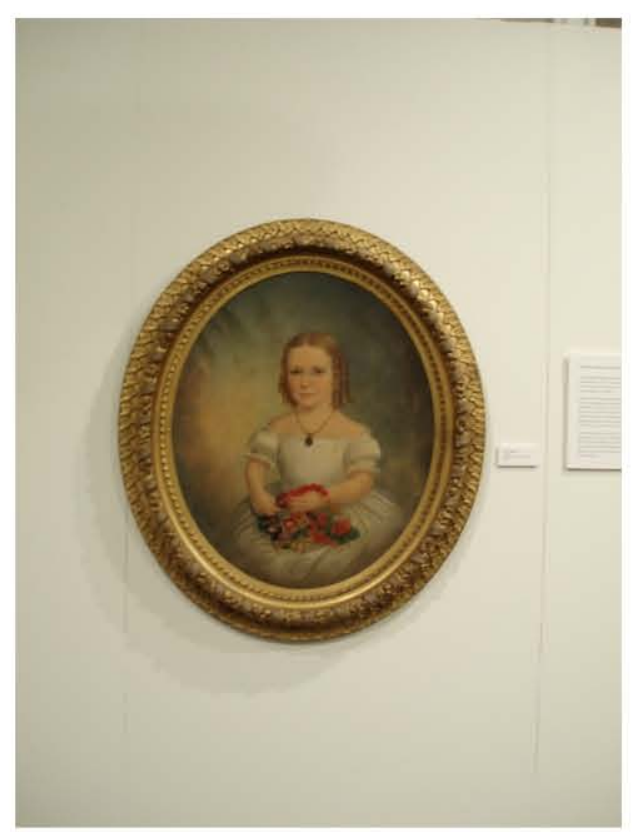

10. Cleon Meekin

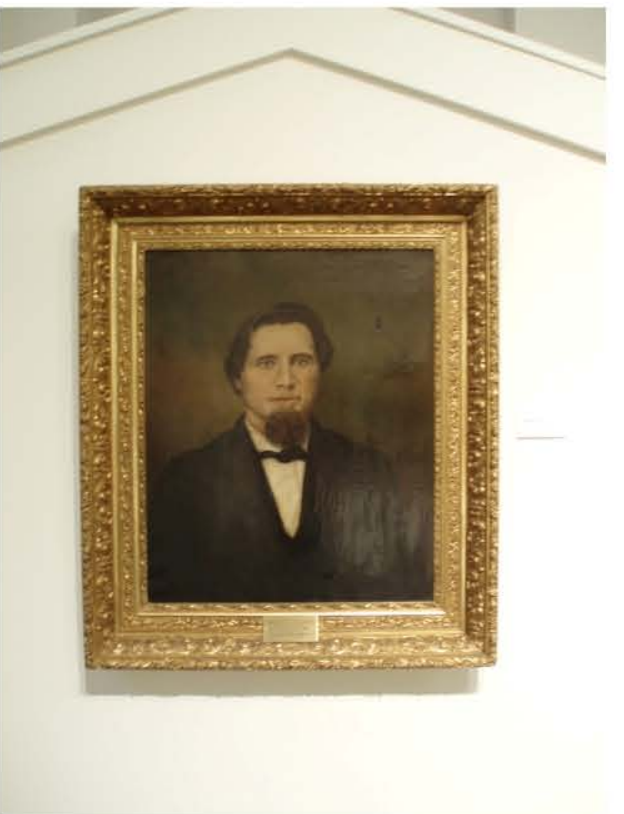

14. George Kraft

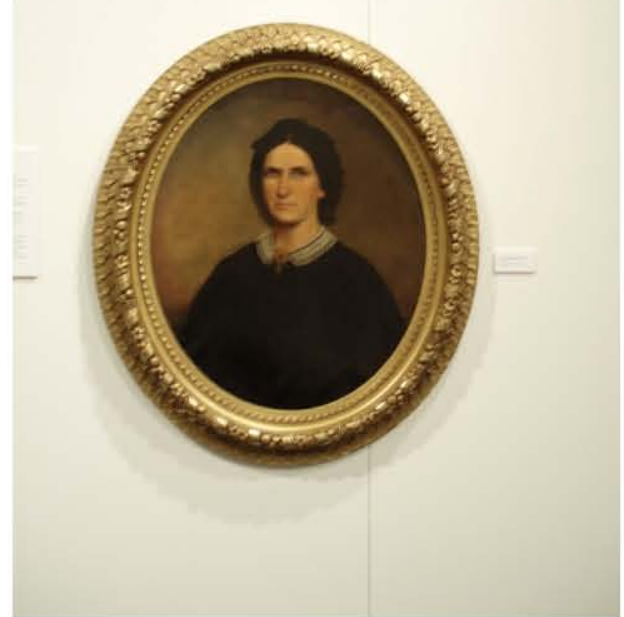

11. Dora Meekin

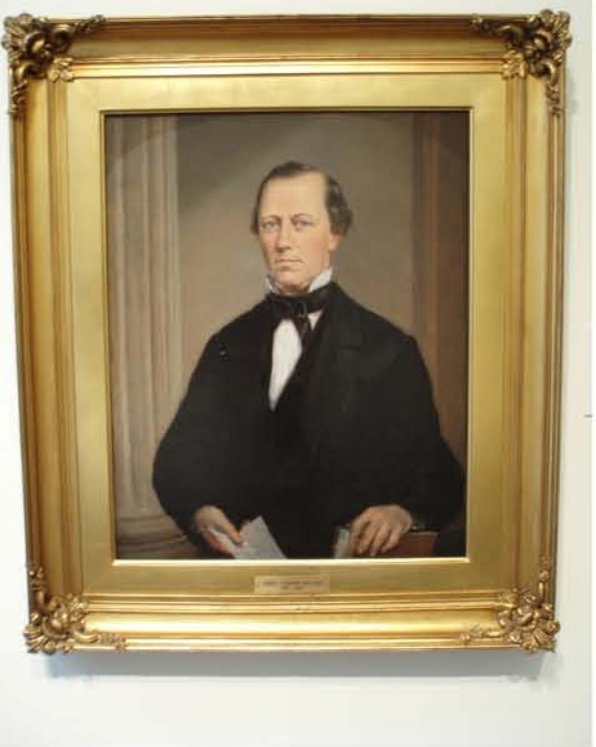

15. Gov. Ashbel Willard

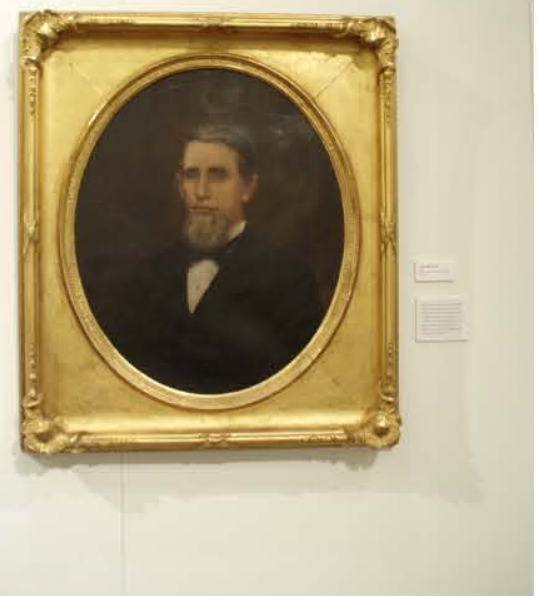

12. John Shrader

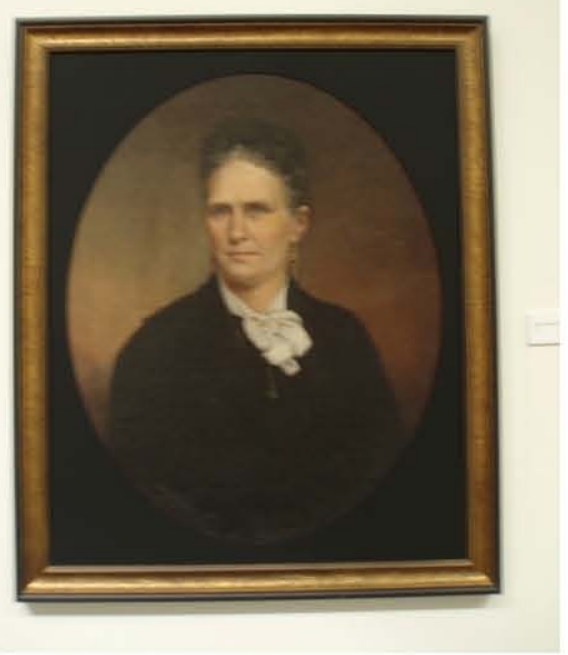

16. Mary Kerr 


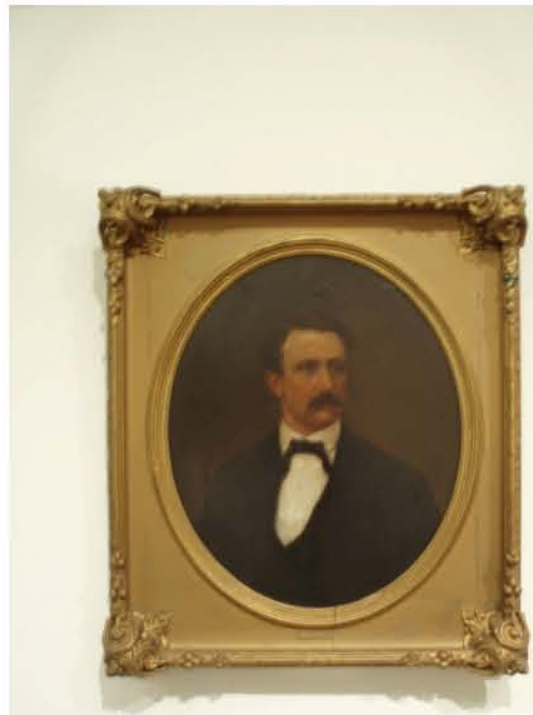

17. Philip Lightfoot Lee

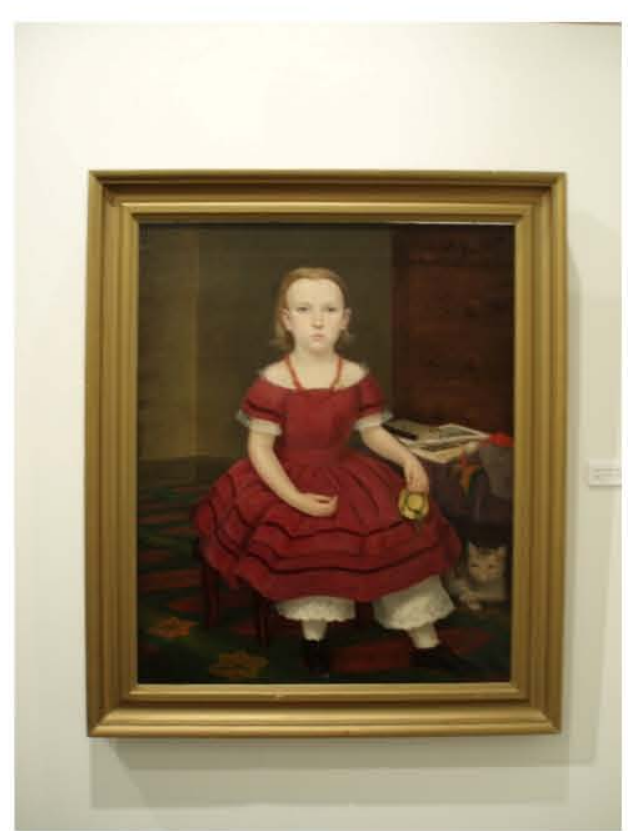

21. Emmadora Townsend

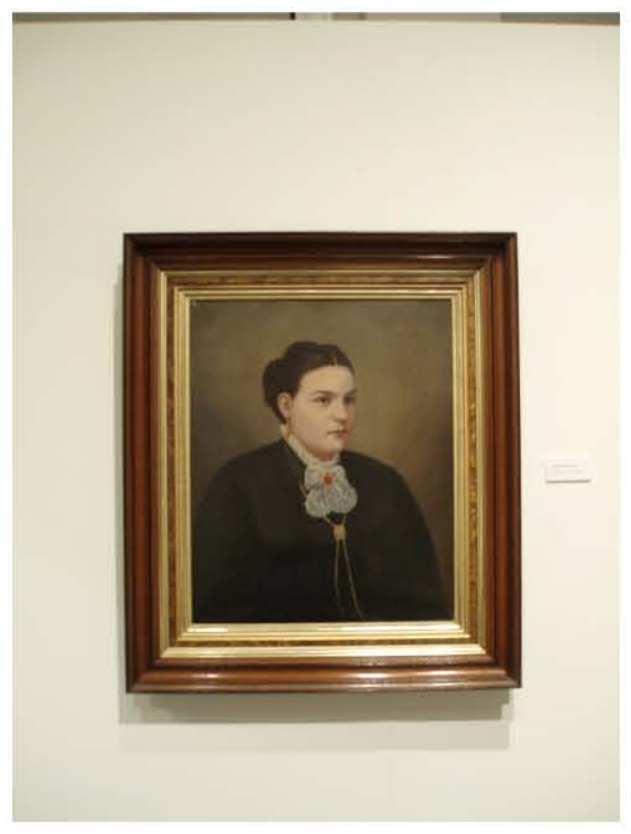

18. Anna Humphries Weir

19. John Owen Greene

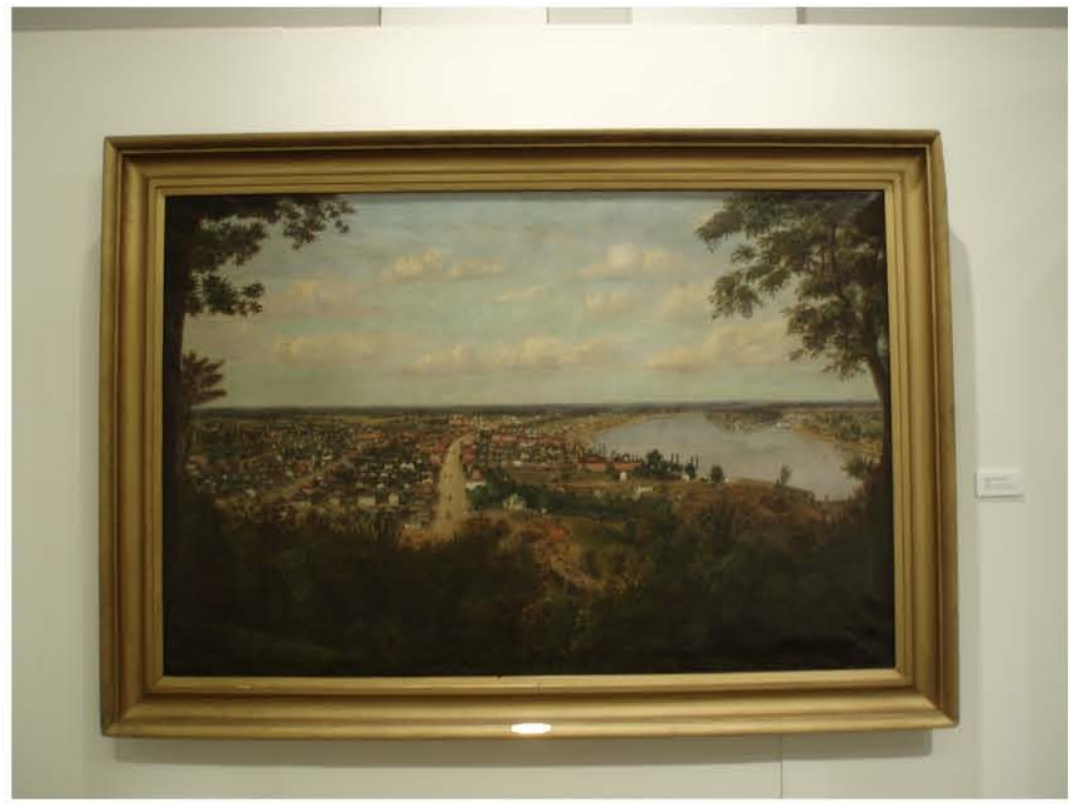

22. George Morrison
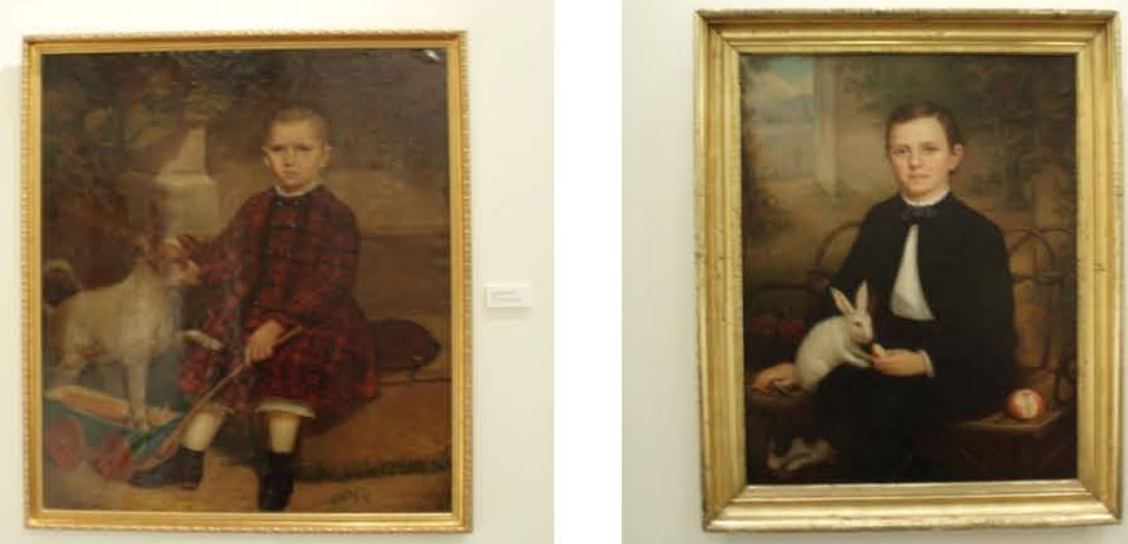

20. Unidentified Child

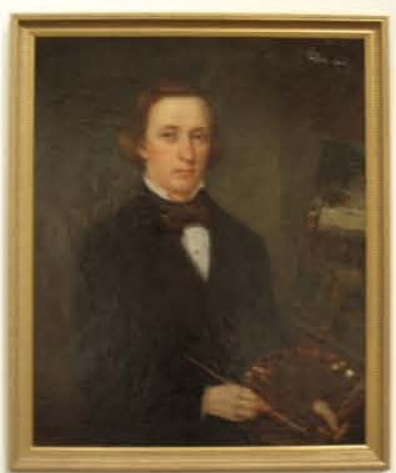

23. View of New Albany 

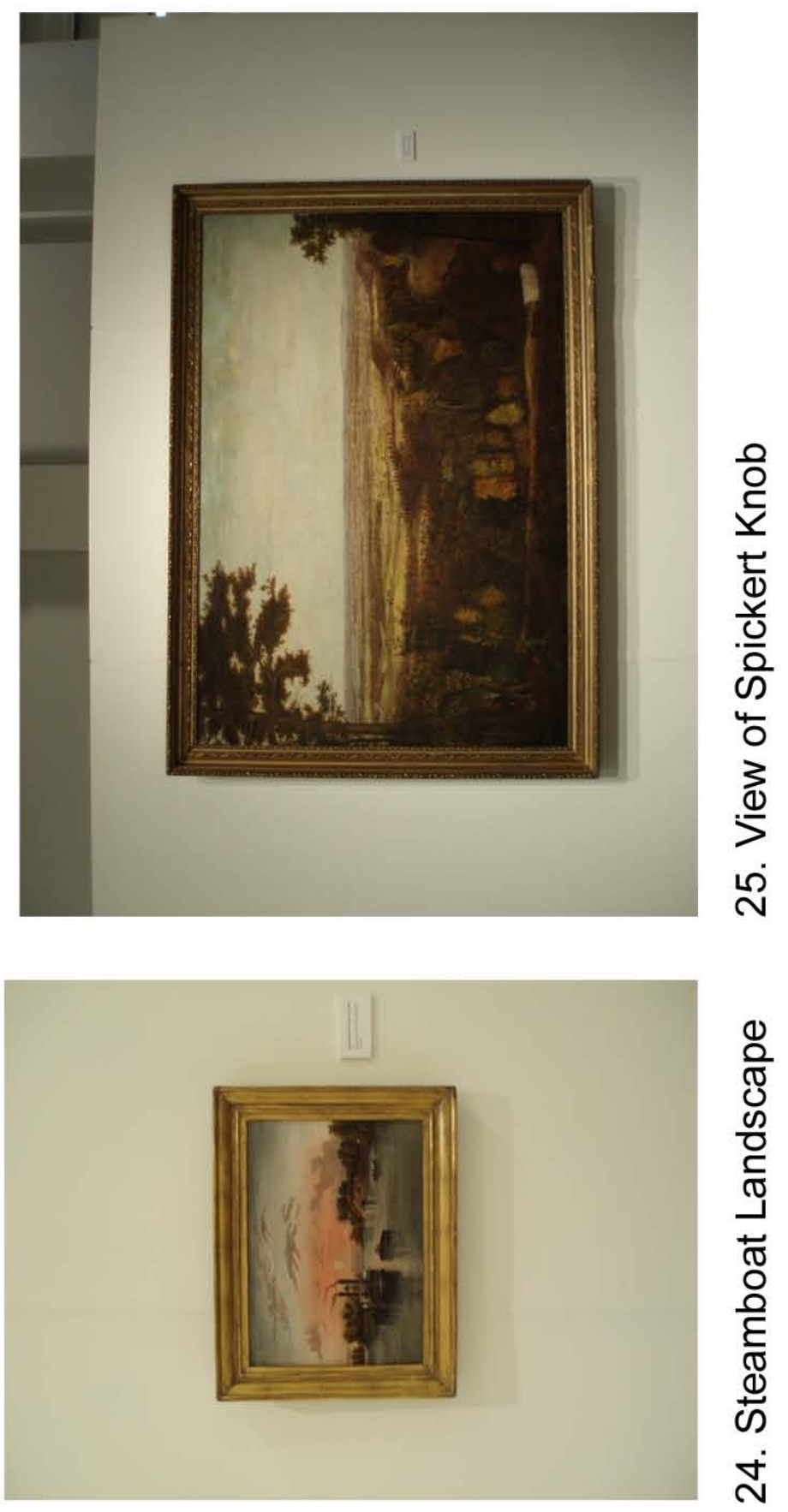
George Morrison (1820-1893)

New Albany’s Portrait Painter

E 1 원

1. Intro Title
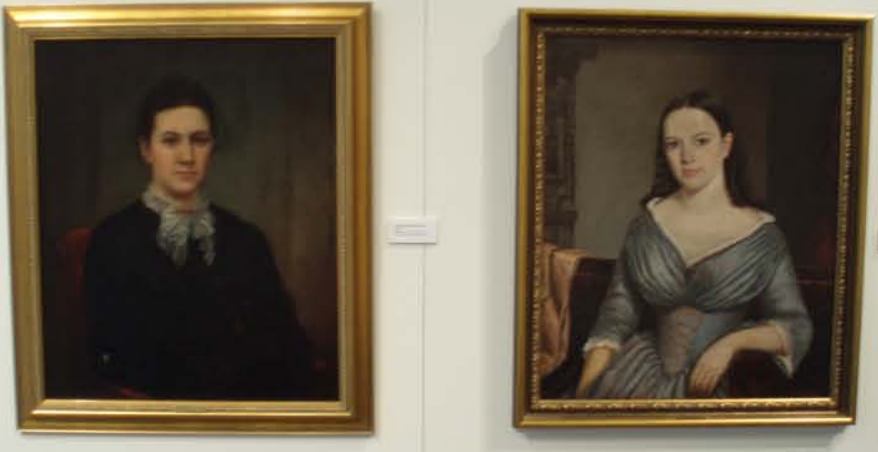

3. Lydia and Mary Morrison
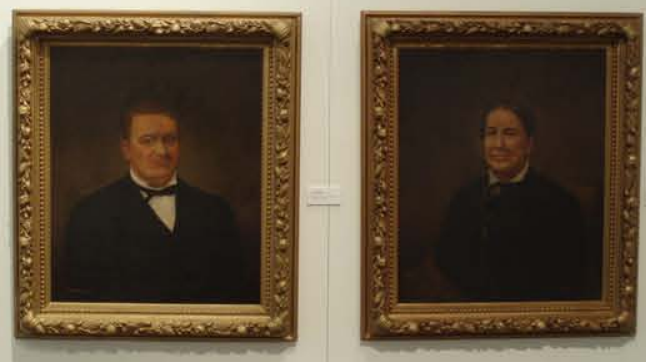

5. John and Mary Briggs
2. Morrison Intro
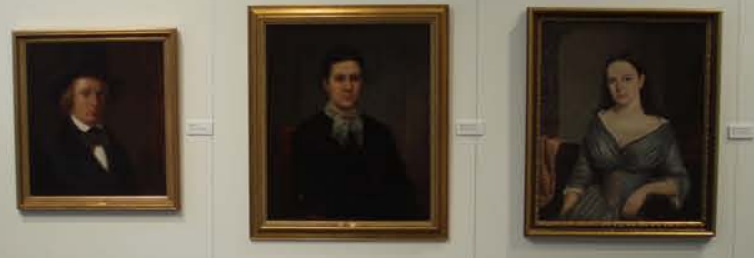

4. Morrison Intro Wall
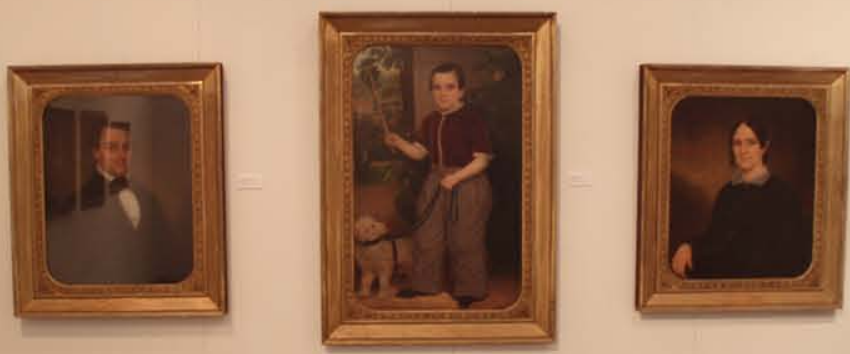


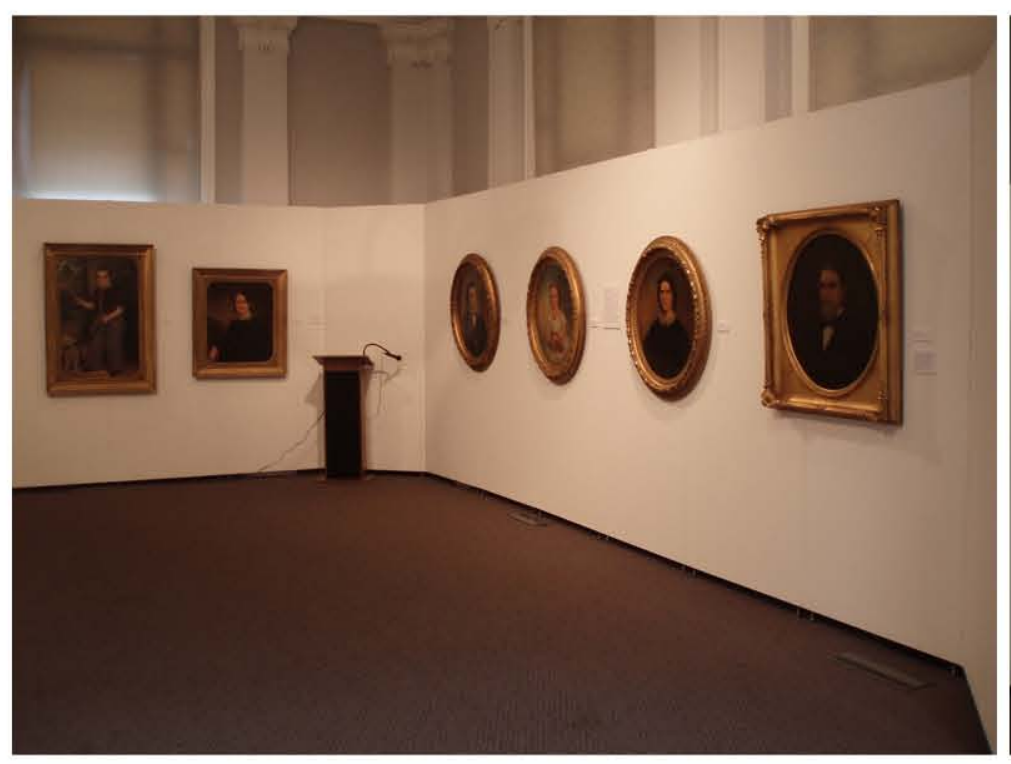

7. Scribner, Meekin Corner

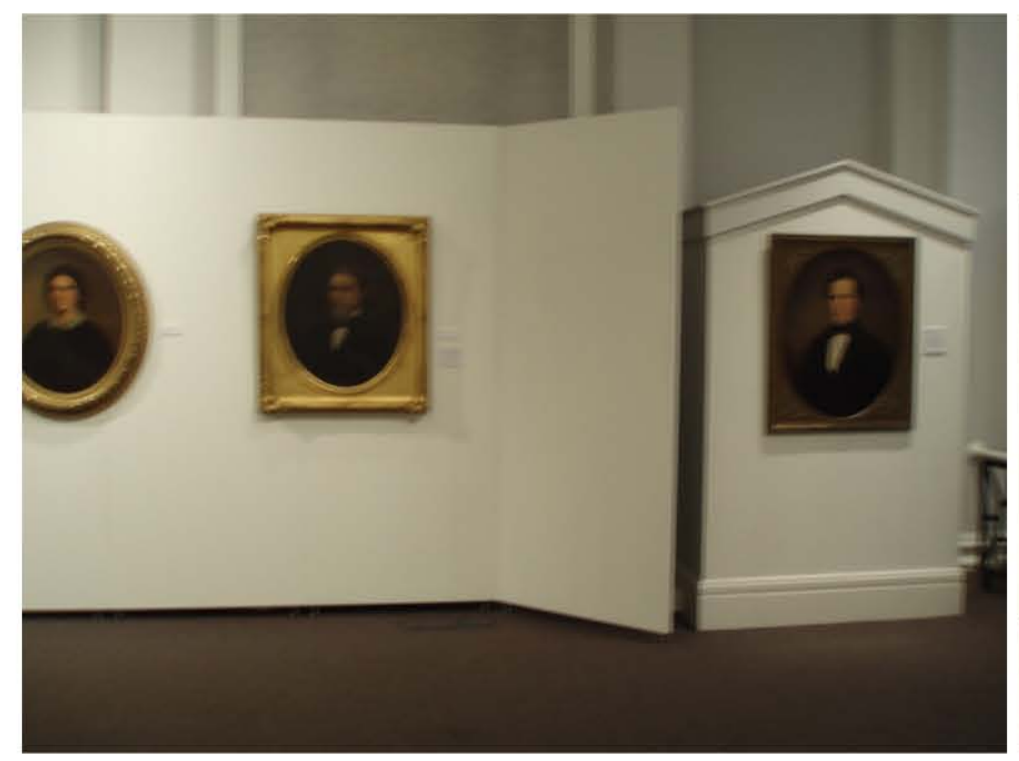

9. Shrader and Judge Davis

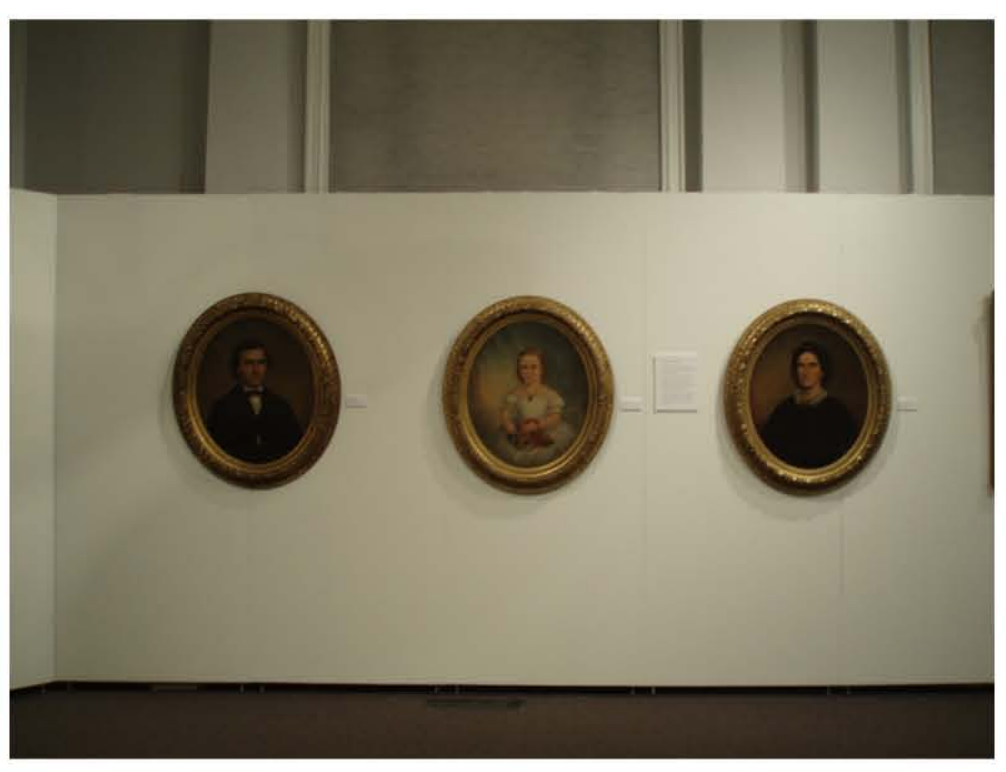

8. Meekin family

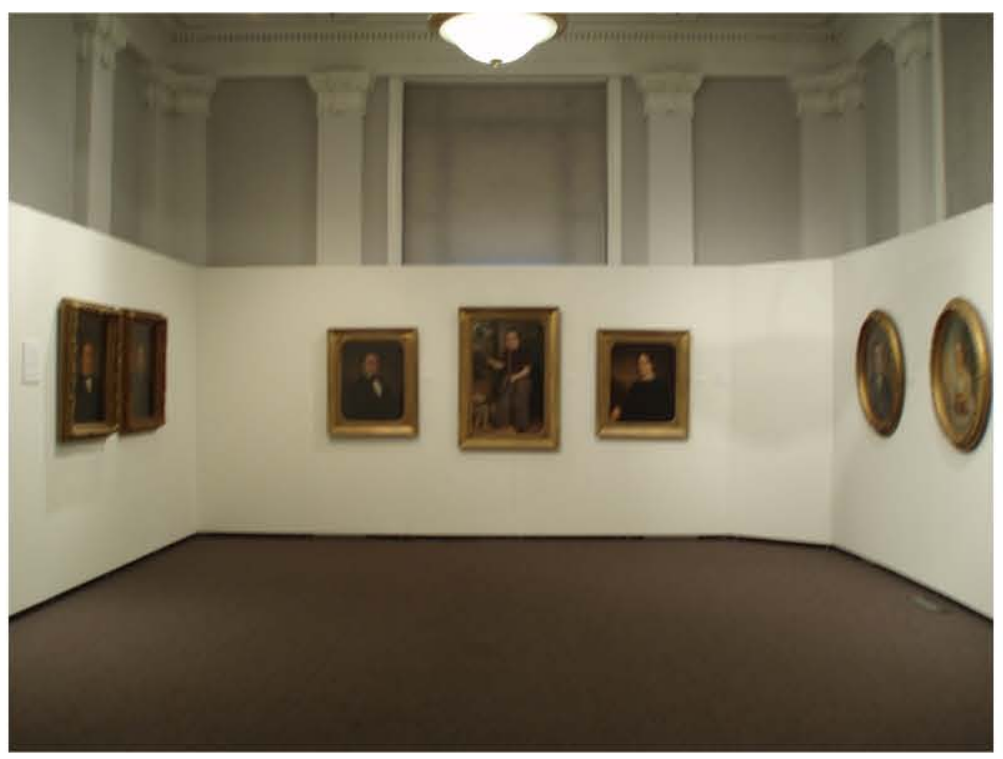

10. Right Gallery view 


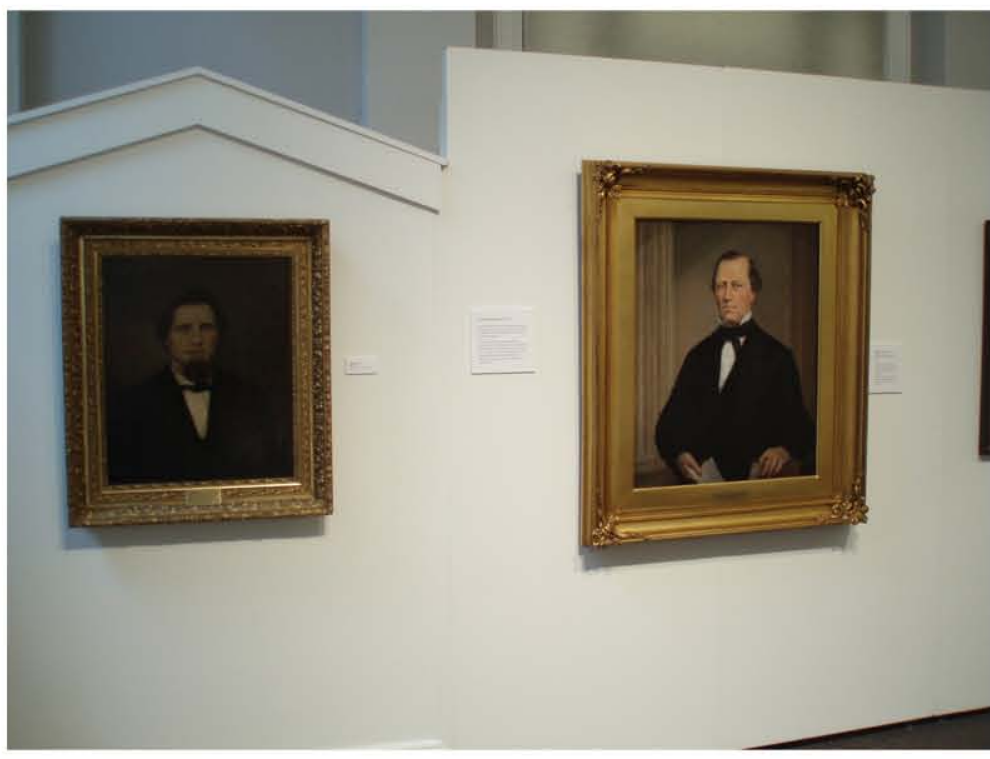

11. Kraft, Willard
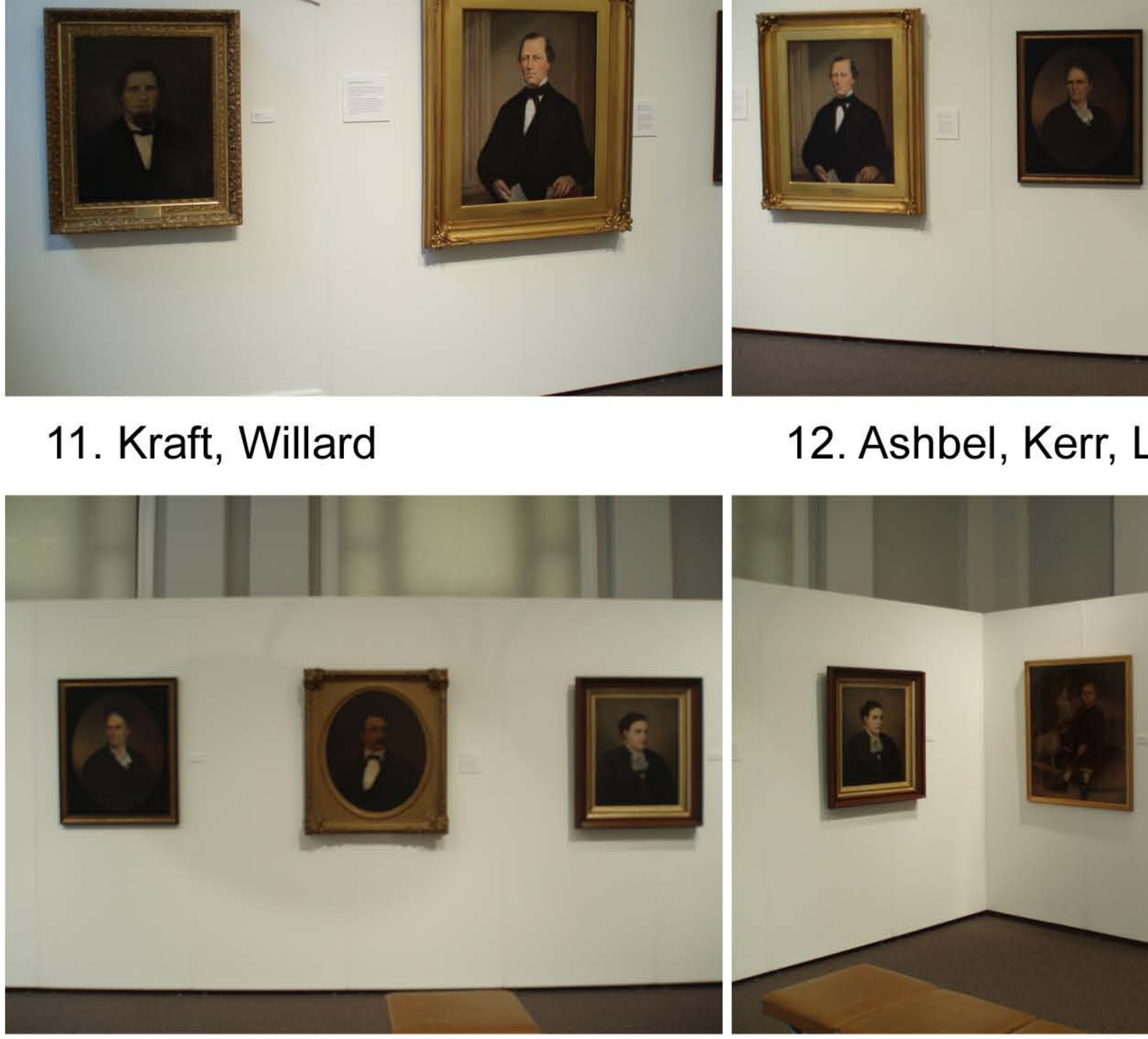

13. Kerr, Lee, Weir

12. Ashbel, Kerr, Lee

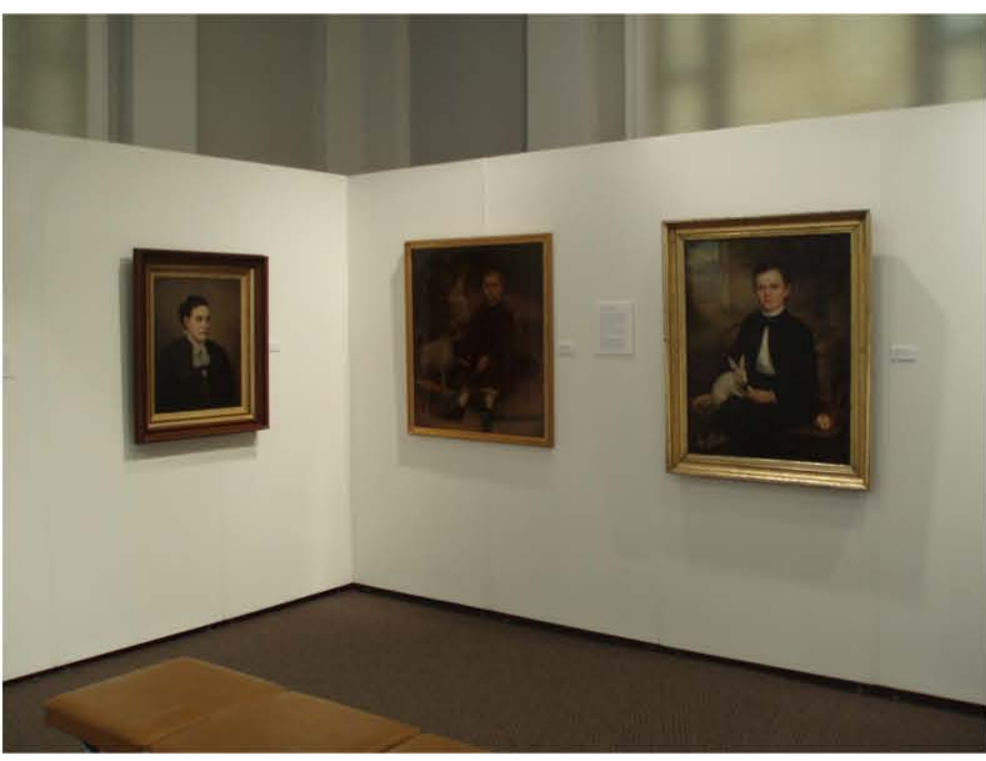

14. Weir, Children wall

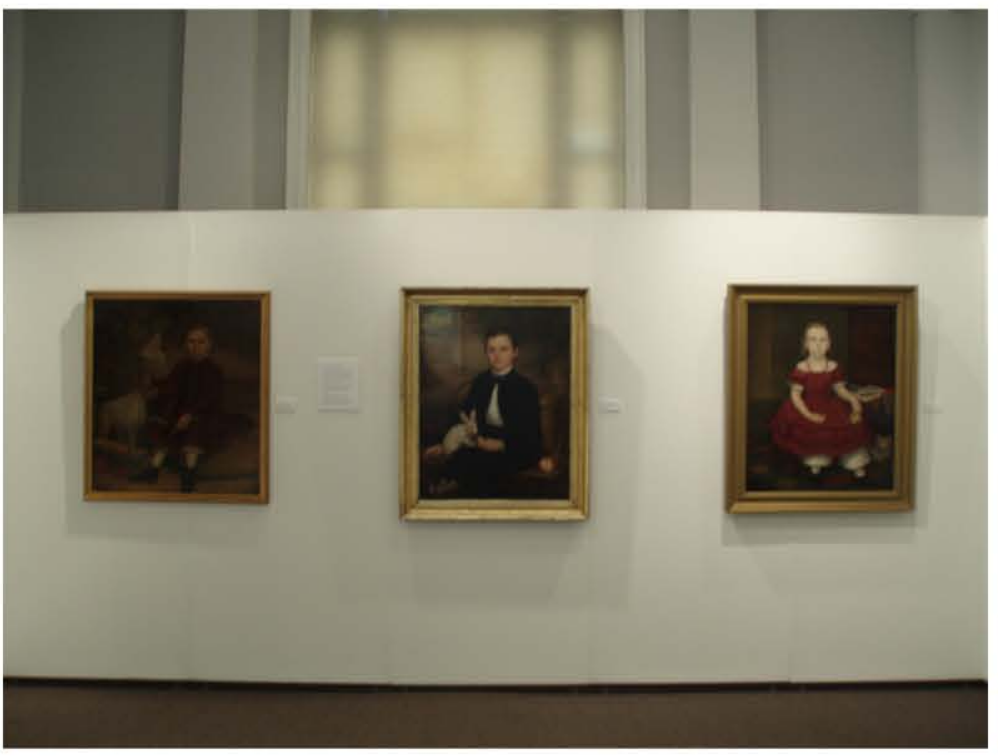

15. Children wall

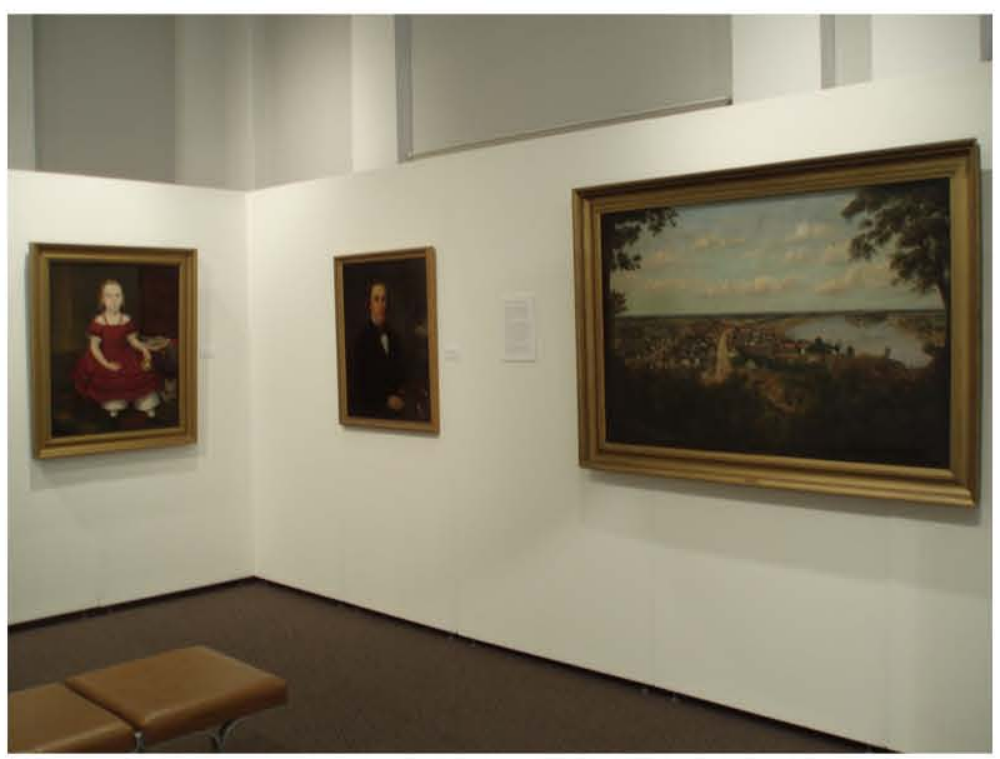

16. Children and Landscapes 


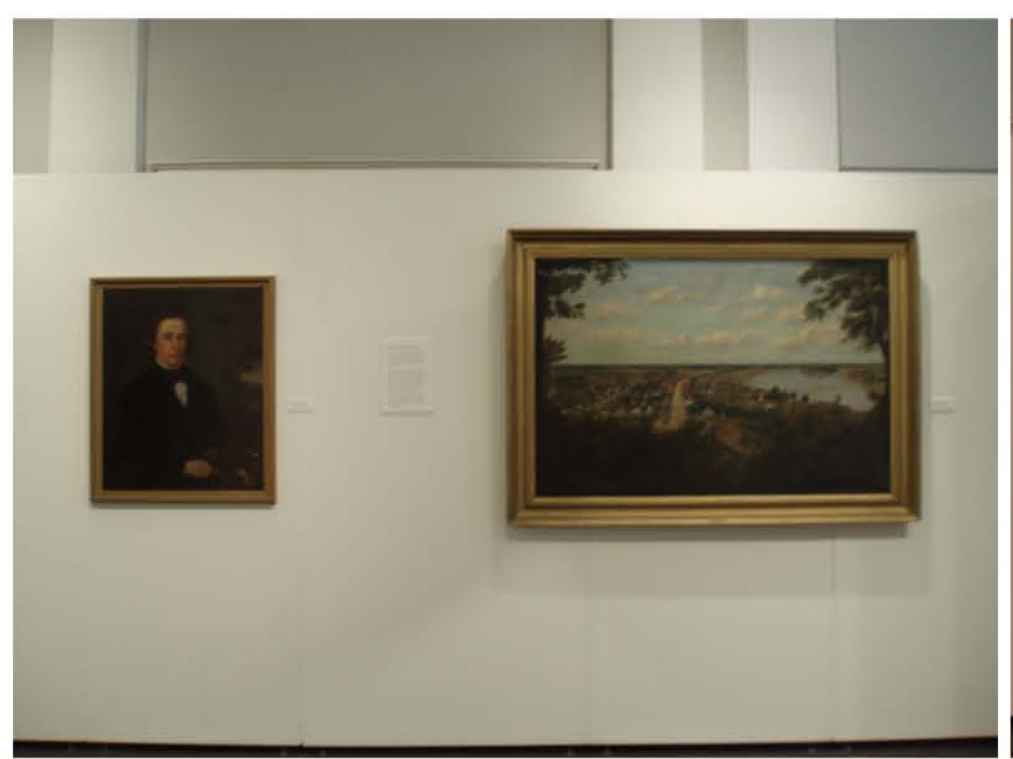

17. Morrison, View of New Albany

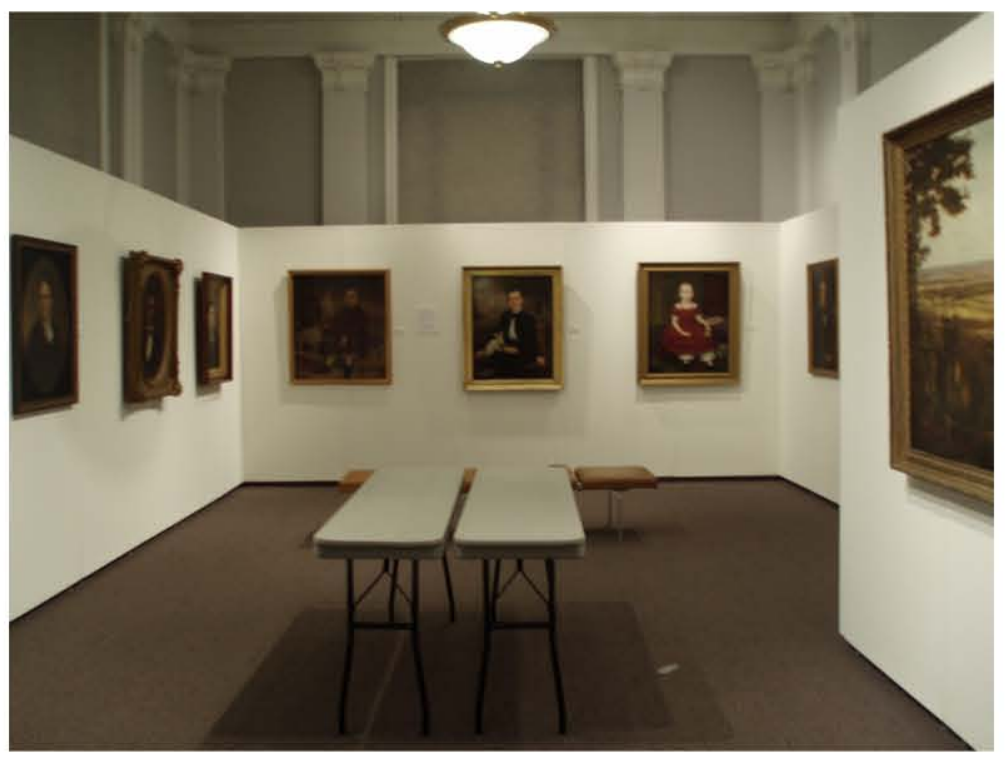

19. Left Gallery

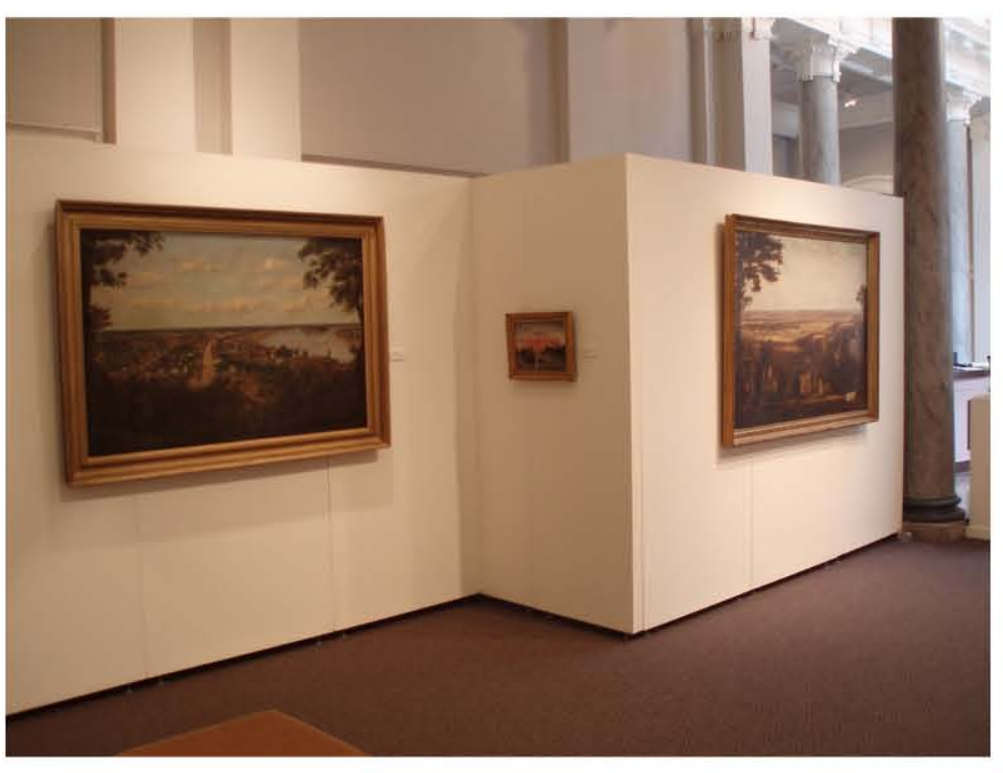

18. Landscapes 